\title{
Cholinergic receptor pathways involved in apoptosis, cell proliferation and neuronal differentiation Rodrigo R Resende ${ }^{* 1,2}$ and Avishek Adhikari ${ }^{3}$
}

Address: ${ }^{1}$ Department of Physics, Institute of Exact Sciences, Federal University of Minas Gerais, Belo Horizonte, MG, 31270-901, Brazil, ${ }^{2}$ Institute of Learning and Research Santa Casa of BH (IEPSC - BH), Belo Horizonte, Brazil and ${ }^{3}$ Department of Biological Sciences, Columbia University, New York, NY, 10027, USA

Email: Rodrigo R Resende* - rrresende@hotmail.com; Avishek Adhikari - aa2369@columbia.edu

* Corresponding author

Published: 27 August 2009

Cell Communication and Signaling 2009, 7:20 doi:10.1186/1478-8IIX-7-20

This article is available from: http://www.biosignaling.com/content/7/1/20

(C) 2009 Resende and Adhikari; licensee BioMed Central Ltd.

This is an Open Access article distributed under the terms of the Creative Commons Attribution License (http://creativecommons.org/licenses/by/2.0), which permits unrestricted use, distribution, and reproduction in any medium, provided the original work is properly cited.
Received: 8 June 2009

Accepted: 27 August 2009

\begin{abstract}
Acetylcholine $(\mathrm{ACh})$ has been shown to modulate neuronal differentiation during early development. Both muscarinic and nicotinic acetylcholine receptors (AChRs) regulate a wide variety of physiological responses, including apoptosis, cellular proliferation and neuronal differentiation. However, the intracellular mechanisms underlying these effects of AChR signaling are not fully understood. It is known that activation of $A C h R s$ increase cellular proliferation and neurogenesis and that regulation of intracellular calcium through AChRs may underlie the many functions of ACh. Intriguingly, activation of diverse signaling molecules such as Ras-mitogenactivated protein kinase, phosphatidylinositol 3-kinase-Akt, protein kinase $\mathrm{C}$ and c-Src is modulated by $\mathrm{AChRs}$. Here we discuss the roles of $\mathrm{ACh}$ in neuronal differentiation, cell proliferation and apoptosis. We also discuss the pathways involved in these processes, as well as the effects of novel endogenous AChRs agonists and strategies to enhance neuronal-differentiation of stem and neural progenitor cells. Further understanding of the intracellular mechanisms underlying AChR signaling may provide insights for novel therapeutic strategies, as abnormal AChR activity is present in many diseases.
\end{abstract}

\section{Introduction}

Acetylcholine (ACh) is an ancient signaling molecule, [1] and is present in both prokaryotes and eukaryotes [2-4]. Although ACh has been extensively studied for its role as a neurotransmitter, it also has autocrine functions [5] in diverse cell types. ACh has been shown to promote cytoskeleton organization, cellular proliferation, differentiation and apoptosis [2-4,6-8] throughout development $[2,3,9]$. Intriguingly $n A C h R$ signaling pathways have been preserved throughout evolution [10], suggesting that they have critical functions. We shall attempt to discuss the physiology of ACh as well as ACh's relevant downstream pathways in apoptosis, cell proliferation and neuronal differentiation of embryonic stem cells.

Interestingly, nicotinic receptors are expressed in undifferentiated and differentiating cells, [8,11-13] suggesting that ACh-mediated signaling between neuronal and nonneuronal cells may influence cell fate $[8,11,12,14]$. Supporting this idea, ACh has been shown to modulate neuronal cell differentiation during development $[15,16]$. Moreover, transfecting a non-neuronal cell line such as a neuroblastoma with choline acetyltransferase induces expression of neuronal markers, muscarinic receptors and 
production of ACh [14]. Lastly, ACh also regulates cell proliferation [17] and apoptosis [18]. These and other findings marked the beginning of a new field: the role of nAChRs in the development and progression of cancer and in stem cell physiology.

\section{Nicotinic ACh receptors}

ACh receptors can be nicotinic (nAChRs), which are ion channels, or G protein-coupled (GPCR) muscarinic receptors (mAChRs). In the central nervous system, nAChRs have been shown to regulate diverse processes such as neurotransmitter release and cellular excitability. Nicotinic receptors also influence physiologic processes such as arousal, sleep, fatigue, anxiety, pain processing, hunger and various higher cognitive functions. [19-22].

\section{nAChRs structure and function}

nAChRs are multisubunit proteins of neuromuscular and neuronal origins. These receptors form ligand-gated ion channels that mediate synaptic transmission both in the neuromuscular junction and between neurons. Since various neuronal nAChR subunits exist, nAChRs can be formed by different combinations of subunits. [23]. Nicotinic receptors of different compositions exhibit different specificities for various ligands and are thereby pharmacologically distinguishable. For example, the elapid alphaneurotoxins that block activation of nAChRs at the neuromuscular junction do not block activation of other neuronal nAChR subtypes [24].

A functional $\mathrm{nAChR}$ consists of five subunits which may be different (certain combinations of $\alpha 1-9$ and $\beta 1-4, \gamma, \delta$, $\varepsilon$ subunits) or identical ( $\alpha 7-9)$ i.e. subunits [25]. All subunits have a similar structure with one extended extracellular domain (N-terminal), four transmembrane domains (M1-M4), one intracellular domain of variable length which joins M3 and M4 domains and one small extracellular C-terminal domain [26]. The binding site for ACh and other agonists is located on the N-terminal extracellular domain at the boundary between $\alpha$ and non- $\alpha$ subunits. In heteromeric neuronal receptors the $\alpha$ and $\beta$ subunits contribute to the binding site The amino acid sequence analysis of various subunits shows that nicotinic receptors can be divided into three sub-classes. The first family includes $\alpha$-bungarotoxin-sensitive muscle-type heteromeric receptors, typically found in skeletal muscle and fish electrical organs, with $(\alpha 1)_{2} \beta 1 \gamma \delta$ and $(\alpha 1)_{2} \beta 1 \gamma \varepsilon$ pentameric structures in fetal and adult form, respectively. The second family includes nAChRs consisting of $\alpha$-bungarotoxin-insensitive, heteromeric subunits. These receptors have various combinations of $\alpha 2, \alpha 3, \alpha 4$ and $\alpha 6$ with $\beta 2, \beta 4, \alpha 5$ and $\beta 3$ subunits. The third family includes $\alpha$ bungarotoxin-binding nicotinic neuronal receptors consisting of five identical subunits $(\alpha 7, \alpha 8$ or $\alpha 9)$ [19].
Neuronal nAChRs are expressed in the autonomic nervous system ganglia, and in the CNS, in post- pre and extra synaptic locations. The $\alpha 7 \mathrm{nAChR}$ subtype is highly expressed in regions of the brain involved in learning and memory, such as the hippocampus and the neocortex [27]. This subtype has a particularly high permeability for calcium ions, increases glutamatergic neurotransmission, and modulates neuronal plasticity by influencing the growth of axons [28].

Studies on the structure, functions and pharmacology of nAChRs neuronal receptors are necessary because these receptors are involved in a large number of nervous system diseases (for review see Clementi and Adlkofer Special Issue on "nicotinic neuronal receptors" 2000).

\section{Muscarinic ACh receptors $m A C h R s$ structure and function}

Muscarinic receptors are members of the G Protein-coupled receptors (GPCRs), and are composed of a family of five receptor subtypes (M1, M2, M3, M4 and M5). These receptors are widely distributed on multiple organs and tissues and are critical to the maintenance of central and peripheral cholinergic neurotransmission. The distribution of these receptor subtypes in the brain and other organs has been extensively studied. M1 is the predominant subtype found in the cerebral cortex and is involved in the control of cognitive functions. M2 is the main subtype in the heart and is believed to play a role in the control of heart rate. M3 is involved in gastrointestinal and urinary tract functioning as well as sweating. M4 is present in the brain and may have a role in locomotion. Lastly, M5, also present in the brain, modulates certain functions of the central nervous system associated with the dopaminergic system, such as dopamine release in the nucleus accumbens following mesopontine stimulation in mice [29]. The M5 subtype is also important for brainstimulation reward [30], opiate reward [31], latent inhibition learning and amphetamine-induced locomotion [3234].

As mAChRs are involved in such a wide array of processes, it is not surprising that muscarinic signaling has been shown to be abnormal in many diseases, such as overactive bladder $[35,36]$, chronic obstructive pulmonary disease $[36,37]$, neurodegenerative disease as Alzheimer's disease [38], dementia [39], Sjogren's disease [40], vascular dementia [41] and others. Consequently, there is considerable interest in finding pharmacological agents to selectively modulate each receptor subtype. Agonists such as muscarine and pilocarpine and antagonists such as atropine have been known for over a century; however, these drugs do not target specific subtypes. Unfortunately, little progress has been made in the discovery of subtype- 
selective compounds making it challenging to study specific functions of individual receptor subtypes. The clinical utility of classic muscarinic antagonists such as atropine is limited due to the high incidence of both peripheral and central adverse effects such as tachycardia, blurred vision, dryness of mouth, constipation, dementia, etc. Atropine derivatives such as ipratropium bromide are better tolerated but most of them lack of selectivity for specific muscarinic receptor subtypes. [42-44]. Thus, the search for subtype selective muscarinic drugs remains an active area of research.

Muscarinic subtypes are coupled to different GPCRs, leading to activation of distinct downstream pathways. M1, M3 e M5 are G-protein coupled receptors (subunit $\alpha$ of the $G_{q / 11}$ family), while $M 2$ and $M 4$ subtypes are coupled to the $\alpha$ subunit of $G_{i}$ and $G_{0}$. Consequently different second messenger dependent-pathways being activated by each muscarinic subtype. For example, phospholipase $C \beta$ (PLC) is activated by M1, M3 and M5, while adenilate cyclase is activated by M2 and M4 subtypes [45]. Processes modulated by pathways involving these G-proteins include smooth muscle contraction (through M2 and M3 receptors), stimulation of glandular secretion (M3 receptors) and inhibition of cardiac voltage-dependent calcium channels (M2 subtypes) [45].

\section{Expression and function of $n-$ and $m A C h R s$ in embryonic cells}

$\mathrm{ACh}[46]$ is present in the brain prior to axonogenesis and synaptogenesis, suggesting that it may mediate non-classical signaling. Furthermore, muscarinic receptors are widely expressed in embryonic cells [8,13,47-54], and have been shown to regulate neuronal cell proliferation and differentiation $[47,50,51]$. In neuronal progenitor cells, muscarinic receptor expression also occurs prior to the onset of synaptogenesis and neurotransmission $[9,55]$, indicating that ACh may act via a local autocrine loop in the embryo. In early development, $\mathrm{M} 2$ receptors are expressed in the dorsal root ganglia neurons, as well as in non-neural cells such as Schwann cells, where they control sensory neuronal differentiation and axonal growth [56]. Intriguingly, muscarinic receptors are also expressed in primary and metastatic tumor cells in which ACh also acts in an autocrine fashion [57]. As discussed above, expression of muscarinic receptors is an embryonic trait. The expression of these receptors in tumor cells $[8,13,58$ 63] likely arises from reactivation of embryonic genes during malignant growth [52]. Proliferation due to mAChR activation has been reported in many tumor cells. For example, activation of muscarinic M1, M3 or M5 muscarinic receptors (but not $\mathrm{M} 2$ or $\mathrm{M} 4$ receptors) induces foci of transformation in 3T3 cells [64,65]. Furthermore, activation of the $\mathrm{Gq}_{\alpha 11}$-coupled muscarinic receptors in various cell lines $[59,66,67]$ or the $\alpha 7$ nicotinic subtype in
P19 embryonic carcinoma cells $[13,68,69]$ induces growth and proliferation. These effects of muscarinic receptor activation depend on the cellular phenotype $[70,71]$. Activation of M3 induces proliferation in human colon cancer cell lines and prostate carcinoma cells [72]. In contrast, activation of endogenous M3 inhibits DNA synthesis in several small cell lung carcinoma cell lines [72]. These contradictory responses also occur in cells transfected with mAChRs, as transfected M3 mAChRs has been reported to both inhibit and stimulate proliferation [73-75]. In cells deprived of trophic factors, muscarinic M3 receptor activation elicits anti-proliferative signals via activation of the small GTP-binding protein, Rac1 $[72,76,77]$. However, muscarinic agonists can also inhibit apoptosis. Pretreatment of tumor cell lines with muscarinic agonists inhibits apoptosis induced by DNA damage [78-81]. Moreover, agonists for M1, M3 and M5 subtypes showed a protective response against apoptosis in Chinese hamster ovary cells transfected with these muscarinic receptors [82]. This effect occurs via a mechanism independent of $\mathrm{Ca}^{2+} / \mathrm{PLC}$ signaling that may involve upregulation of the anti-apoptopic protein $\mathrm{Bcl}-2[6,83]$. It is unclear whether muscarinic receptor activation is related to tumor growth and stem cell proliferation $[8,84$ 87]. In addition to morphogenesis, non-neuronal muscarinic receptors also control cell migration, as M3, M4 and M5 subtypes were shown to control cell migration by facilitating fibronectin-induced movement [58,88-90]. Contraction and aggregation of cells in embryonic tissue is also induced by muscarinic receptor activation [91]. In this way, mAChRs could modulate cellular movement during morphogenesis $[92,93]$.

\section{Apoptotic signaling pathways Apoptotic pathways associated with mAChRs}

Many G-protein-coupled receptors protect cells from apoptosis induced by growth factors, DNA damage or cellular stress. Among those receptors, mAChRs have been shown to be protective in many cell lines and primary cell cultures $[8,78-80,94,95]$. These reports raise the possibility that damage to cholinergic pathways might contribute to the development of neurodegenerative disorders, such as Alzheimer and Huntington. In some neurodegenerative disorders losses of neuronal survival stimuli occur, leading to cell death. It is known that mAChRs inhibit apoptosis through activation of PI3-kinase (phosphatidylinositol-3-OH kinase) and its downstream targets, protein kinase B (PKB)/Akt and MAPK/ERK (Figure 1) [96]. These kinases activate pro-survival pathways in diverse cell types [96], including neurons $[97,98]$. Previous work $[77,80,99-101]$ has demonstrated that Akt can be activated effectively through $G_{q}$ coupled to $M 1$ and $M 3$, and $\mathrm{G}_{\mathrm{i}}$ coupled to M2. Activation of Akt occurs through $\beta \gamma$ complexes and the $\alpha, G \alpha_{\mathrm{q}}$ and $\mathrm{G} \alpha_{\mathrm{i}}$ subunits of Gs proteins. The cell survival effects mediated by mAChRs are 


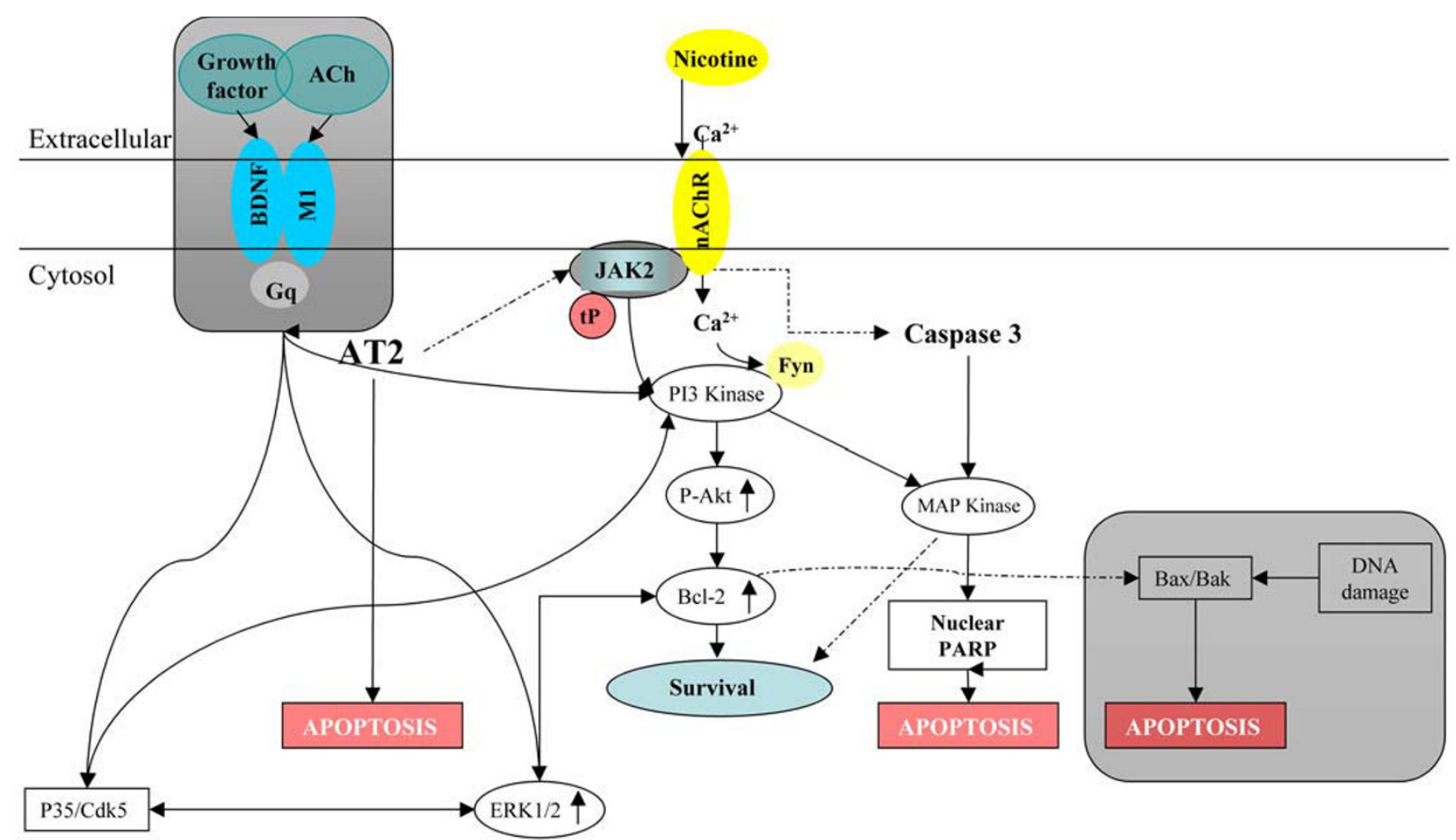

Figure I

Diagram depicting apoptotic pathways modulated by $\mathrm{nAChRs}$ and $\mathrm{mAChRs}$ in neuronal progenitor cells. See text for a better description.

partially blocked by inhibitors of the PI3-kinase MAPK/ ERK pathways [99]. Interestingly, Lindenboim et al., [78], have demonstrated that the protective effects of ACh in undifferentiated and neuronal PC12 cells require M1 receptors. In this condition, expression of M2 receptors decreases DNA synthesis, arresting the cell cycle at $S$ and $G_{2} / M$. Furthermore, activation of M1 and M3 receptors inhibits caspase 2 and 3, and this effect has been shown to be independent of PI3-kinase and MAPK/ERK pathways $[77,79,102]$. Previous reports have described cholinergic signaling in progenitor and tumoral cells. Gutkind and collaborators [73] showed how mAChRs exert oncogenic control in neuronal cell growth by regulating signaling of extracellular-1/2/MAP. Similar results were also obtained in non-neuronal cell types [103-105]. Although it is unclear if mAChR activation is related to oncogenic progression, there are reports suggesting that inhibition of mAChRs decrease cell proliferation $[8,106]$. In line with these results, previous work showed that apoptosis can be induced in Chinese hamster ovary cells transfected with the M3 receptor and exposed to toxic substances [83]. This effect might be related to caspase action, considering that M3 receptor activation did not prevent cell death. This process may be specific for $\mathrm{G}_{\mathrm{q} / 11}$ coupled muscarinic sub- types, specifically M1, M3 and M5 [79,83]. However, the use of a version of M3 truncated at its carboxyl end revealed that this protection is not mediated by PLC or by phosphorylation of its receptor. Moreover, these pathways are not involved in activation of ERK and JNK, so presumably, the anti-apoptotic actions of mAChRs are not mediated by these proteins, but through its own C terminal domain, which is rich in basic residues [83]. The mechanism through which mAChRs mediate cell survival is dependent on transcription of the anti-apoptotic protein Bcl-2, which can be induced by mAChRs [83]. This protective feature of mAChRs may be a conserved among other G-protein coupled receptors.

By targeting two signaling pathways, the MAPK/ERK pathway $[107,108]$ and the PI3-kinase signaling pathway [109], it would be possible to gain new insights on the intracellular signaling pathways through which mAChRs inhibit apoptosis. It has been suggested that these pathways inhibit caspases $[77,79,102]$. To this end, it was shown that PKB/Akt, the downstream target of PI3-kinase, can inhibit both caspase-9, [110-112] and the pro-apoptotic protein Bad [112-115]. However, PKB/Akt can also be activated by other pathways. These are mediated by 
protein kinase A (PKA), calcium/calmodulin-dependent kinase and Bad [114,116-119]. Interestingly, inhibitors of the PI3-kinase or MAPK/ERK pathways could not suppress the muscarinic effect on caspases, although all were able to inhibit the muscarinic-dependent phosphorylation of PKB/Akt and MAPK/ERK. Furthermore, previous studies in PC12 cells have shown that these inhibitors block survival effects and ERK and PI3-kinase signaling $[120,121]$. It has been suggested that the MAPK/ERK and PI3-kinase pathways are not essential for mediating the muscarinic effect on caspase activity in PC12 cells [79], but rather that this effect is mediated by an unidentified pathway. This finding is in line with recent studies showing that in some cases the survival effects of growth factors and cytokine receptors are mediated by pathways independent of both MAPK/ERK and PI3-kinase. For example, neither the survival effect of nerve growth factor (NGF) on sympathetic neurons [122] or rat-1/MycER cells transfected with TrkA [123], nor that of granulocyte/macrophage colony-stimulating factor on MC cells, is mediated by the PI3-kinase pathway [124]. Moreover, the MAPK/ ERK and the PI3-kinase pathways are not essential for the survival effect of NGF on apoptosis induced by ceramide in PC12 cells [121]. However, the PI3-K/Akt pathway has an established role in NGF-promoted cell survival [125]. Activation of PI3-K by NGF initiates a cascade involving Akt, which leads to the phosphorylation and inhibition of the pro-apoptotic protein Bad and activation of the prosurvival inhibitor $\kappa B$ kinase $\alpha(I K K \alpha)[116,126]$. Blockade of the PI3-K/Akt pathway by a dominant negative Akt mutant or treatment of cells with PI3-K inhibitors reveal that activation of this signaling pathway is required for NGF-promoted cell survival [127]. However, it was shown that pertussis toxin did not inhibit Akt phosphorylation. This finding is consistent with the previous observation of pertussis toxin having a more profound inhibitory effect during the early phase of NGF-induced Erk1/2 activation [128]. Upon activation, the TrkA receptor activates the PI3-K pathway, leading to activation of Akt in sympathetic neurons [125]. Previous studies have shown that TrkA forms complexes with GRK2 and GAIP/GIPC (GAIP-interacting protein, $C$ terminus) $[128,129]$, thereby providing a bridge to link TrkA and $\mathrm{G}$ protein signaling pathways. Furthermore, there is prior evidence pointing to a functional association between pertussis toxin-sensitive $G$ proteins and growth factor receptors such as the insulin receptor tyrosine kinase [130]. In addition, some pertussis toxin-sensitive growth factor-induced responses have been reported. For example, insulin-like growth factor 1 has been shown to activate $G_{i}$ and release $G \beta \gamma$ subunits $[131,132]$, while TrkA is able to utilize $\mathrm{G}_{\mathrm{i} / \mathrm{o}}$ to stimulate Erk1/2 [128,133]. Increasing evidence shows that GPCRs often cooperate with RTKs (receptor tyrosine kinases) in the regulation of numerous signal transduction pathways [134-136]. More recently, a report has demonstrated that
NGF and lysophosphatidate receptor signaling systems can interact to promote $\mathrm{G}$ protein-mediated activation of the Erk pathway [133]. These observations are consistent with the notion that TrkA can utilize pertussis toxin-sensitive $G_{i / o}$ proteins to activate Akt, thereby inhibiting Bad and stimulating the NFKB regulator, IKK, via $G_{\alpha \gamma}$ activation $[137,138]$ to allow cell survival through the M3 subtype $[83,139,140]$.

One candidate for mediating the muscarinic effect on caspases is sphingosine-1-phosphate, which was shown to play an important role in the survival effect of NGF on PC12 cells [141]. Interestingly, sphingosine-1-phosphate can be induced by the M2 muscarinic receptor [142]. Intriguingly, inhibition of the PI3-kinase pathway partially attenuates the muscarinic survival effect on the viability of the cells but not on caspase inhibition. One possible explanation is that serum-deprived cells can die via both caspase-dependent and -independent pathways, as shown in some apoptotic paradigms such as Baxinduced cell death in the presence of caspase inhibitors [143-145]. Despite the fact that the caspase-dependent pathway seems to play a major role in the death of serumdeprived PC12 cells, it is possible that once this pathway is inhibited, the caspase-independent pathway has a major role. However, one cannot exclude the possibility that there are unknown caspases which are activated and involved in apoptosis induced by trophic-factor-deprivation and that these caspases are inhibited by the muscarinic receptor in a different mechanism than that used to inhibit the DEVDase caspases and caspase-2. It was shown that NGF withdrawal from differentiated PC12 cells induces expression of FasL, which in turn may contribute to the apoptotic process via activation of the CD95 receptor $[146,147]$. In this case, it is still possible that muscarinic receptors will inhibit the activation of caspase8 , the caspase which is directly activated when CD95 is activated $[80,115,148]$ by a PI3-kinase-dependent mechanism as was shown for CD3 activation in Fas-treated Th2type cells $[80,115]$. In some systems, one signaling pathway appears to be sufficient for mediating survival induced by trophic agents such as NGF (PI3-kinase) and $N$-acetylcysteine (ERK) $[109,120]$. However, in other systems, the survival effect may require the combined action of several signaling pathways. For example, insulin-like growth factor-1 inhibited apoptosis in differentiated PC12 cells requires both PI3-kinase and MAPK/ERK signaling pathways $[127,149,150]$. It has been suggested that the muscarinic survival effect could be mediated by the combined effect of at least two different pathways. One pathway may lead to caspase inhibition and be independent of PI3-kinase and ERK signaling. This pathway could be mediated by the $\mathrm{G}_{\mathrm{i} / \mathrm{o}}$-coupled receptors. The other pathway would act through $\mathrm{G}_{\mathrm{q}}$ and may involve the PI3kinase pathway, and could promote survival by a mecha- 
nism that does not affect caspases and that could be mediated by the $\mathrm{G}_{\mathrm{q}}$-coupled receptors.

Previous reports showed that muscarinic receptor stimulation leads to activation of the Rho family of small G-proteins $[151,152]$. This pathway can lead to activation of Rho kinase [153] and is critical for the protective capacity of muscarinic receptors. It has been demonstrated that excitatory receptor agonist-induced Rho activation is $\mathrm{Ca}^{2+}$-dependent [154]. The ability of mAChRs to activate SRF-mediated gene transcription and the involvement of $G$ protein subunits in SRF activation were investigated in Jurkat $\mathrm{T}$ cells. It has been shown that $\mathrm{G \alpha}_{\mathrm{q}}$-coupled $\mathrm{M} 1$, but not $\mathrm{G \alpha}_{\mathrm{i} / \mathrm{o}}$-coupled $\mathrm{M} 2$ receptors can activate $\mathrm{SRF}$ through a RhoA-mediated pathway $[73,155]$. In contrast, M3 mAChR failed to activate SRF even though M1 and M3 are thought to induce similar signaling pathways that involve $\mathrm{G} \alpha_{\mathrm{q} / 11}$. Yet, $\mathrm{G} \alpha_{\mathrm{q}}$ coupling of both $\mathrm{M} 1$ and $\mathrm{M} 3$ remained intact, as revealed by a robust calcium response in Jurkat $\mathrm{T}$ cells. Moreover, use of the chimeric G $\alpha$ protein construct $\mathrm{G \alpha}_{\mathrm{iq} 5}$, which allowed the M2 receptor to signal along $\mathrm{Ga}_{\mathrm{q} / 11}$-mediated pathways, restored the $\mathrm{Ca}^{2+}$ response for M2, but not SRF activation. This suggests either that the activation of SRF through M1 involves a $\mathrm{G} \alpha_{\mathrm{q} / 11}$-independent pathway or that $\mathrm{G \alpha} \alpha_{\mathrm{q} / 11}$ is insufficient in Jurkat T cells. The inhibition of M1-SRF signaling by cotransfection with the $\mathrm{G} \alpha_{\mathrm{q} / 11}$ suppressors, RGS2 and RGS4, indicated that $\mathrm{G} \alpha_{\mathrm{q} / 11}$ did play a role in M1-SRF activation, but it appeared to be insufficient per se. However, an increase of M1-SRF signaling inhibition was observed when intracellular calcium was decreased.

\section{Apoptotic pathways associated with nAChRs}

Nicotinic receptors are expressed in neural and non-neuronal tissues; however, in the latter their function is not clear. Although nAChRs are primarily known for their action as ligand-gated ion channels transducing action potentials across synapses, they may have other actions as well, such as cell-to-cell communications in various nonneuronal tissues controling important cell functions such as proliferation, adhesion, migration, secretion, survival and apoptosis in an autocrinal, justacrinal and paracrinal manner [22]. Interestingly, nicotinic receptors in neurons protect against cell death in some settings $[8,12,68,81]$. In neurons, the $\alpha 7$ nicotinic receptor activates PI3-kinase through a src-family kinase, activating the anti-apoptotic kinase AKT [156]. One pathway involved in AKT signaling involves phosphorylation of the forkhead transcription factor FKHRL1, causing its retention in the cytoplasm associated with 14-3-3. This in turn blocks expression of the apoptotic protein fas [157]. The PI3-kinase/AKT pathway protects a broad range of neurons against apoptotic cell death and may block apoptosis triggered by beta-amyloid fragments, which contribute to progression of Alzheimer's disease. If so, nicotinic agents may prove useful in the treatment of this and other neurodegenerative conditions. Interestingly, removal of extracellular $\mathrm{Ca}^{2+}$ suppressed Akt phosphorylation induced by nicotine. It was shown that an inhibitor of Src tyrosine kinase also reduced Akt phosphorylation. In addition, PI3-K and Fyn are physically associated with $\alpha 7$ nicotinic receptors. Therefore, nicotinic receptor stimulation might lead to phosphorylation of Akt through Fyn [157-159]. The $\alpha 7$ subtype can mobilize $\mathrm{Ca}^{2+}$ from ryanodine-sensitive intracellular stores and promote cell survival $[8,13]$. This intracellular $\mathrm{Ca}^{2+}$ mobilization can lead to BDNF-induced Cdk5-mediated neuroprotection through increased Bcl-2 expression. (Figures 1 and 2). Nicotine has also been shown to regulate the Bcl-2 family of proteins. For example, nicotine induces phosphorylation of $\mathrm{Bcl}-2$ leading to protection of human small cell lung carcinoma cells against cisplatin-induced apoptosis [160,161]. Moreover, nAChRs heterodimers containing $\alpha 3$ and $\alpha 4$ mediate their apoptotic activity in normal human bronchial epithelial cells through Akt [162]. Lastly nicotine also phosphorylates downstream targets of Akt, such as mTOR, FKHR, elf-4, GSK3b, tuberin and S6K [162].

Nicotine can also promote anti-apoptotic effects through activation of PKC, PKA and NF- $\mathrm{KB}$, and downregulation of the tumor suppressor p53 [160,161]. Nicotine-induced NF- $\kappa B$ phosphorylation promotes the phosphorylation of the apoptotic protein Bad (Bcl-2 antagonist of cell death), which becomes inactivated and prevents cell death. Other pathways underlying the anti-apoptotic effects of nicotine include the MEK and PI3K pathways [163]. It was previously shown that ERKs, AKT, and PKA could function as a Bad Ser ${ }^{112}$, Ser ${ }^{136}$, or Ser ${ }^{155}$ kinase, respectively [164-167]. One interesting study demonstrated that nicotineinduced Bad phosphorylation is mediated by $\beta$-adrenergic receptors [163] (for a review see [168]), and that nicotine can also induce phosphorylation of Bax (another Bcl-2 antagonist of cell death) through $\mathrm{PKC}$, thereby inactivating Bax and suppressing cell death $[169,170]$.

The protective effects of nicotine have been studied in NSCLC and PC12 cell lines, as well as in other experimental systems [171-176]. Nicotine can protect A549 NSCLC cells against apoptosis induced by anticancer drugs through the upregulation of XIAP and survivin in a $\alpha 3$ nAChR-dependent manner [171]. Furthermore, administration of nicotine in the CNS can stimulate release of neurotransmitters $[177,178]$ and neurotrophic factors, such as basic fibroblast growth factor (bFGF or FGF-2) and brain-derived neurotrophic factor (BDNF)[179]. In addition, nicotine exposure can lead to elevated cellular cAMP levels [180]. It was demonstrated that nicotine attenuates both arachidonic acid-induced caspase activation and apoptosis of spinal cord neurons [181]. However, controversy exists on the specific nAChR subunit 


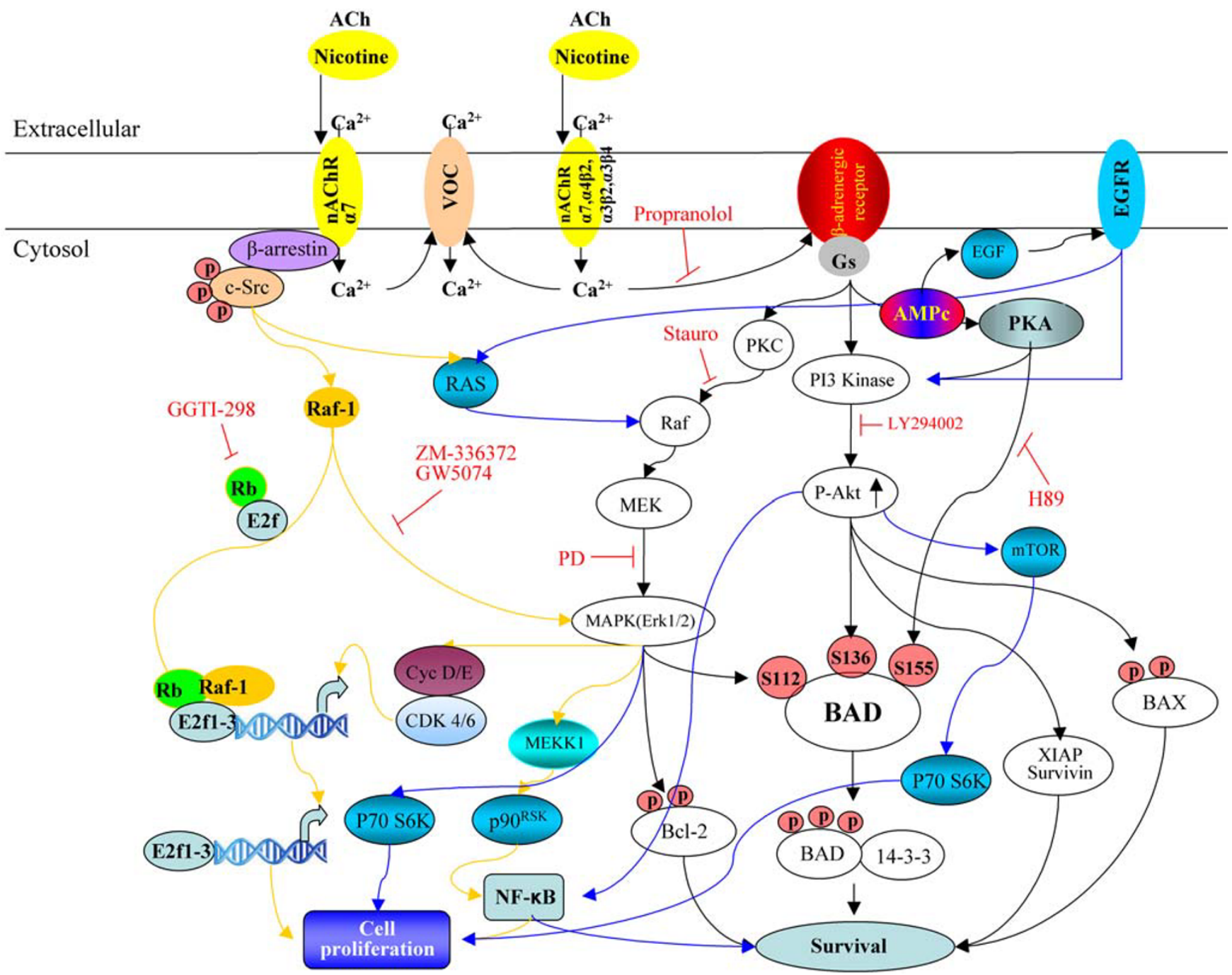

Figure 2

Diagram depicting proliferative and survival signaling pathways in cells. In vitro, the homomeric and heteromeric $\mathrm{nAChRs}$ jointly stimulate the indicated signaling cascades. Yellow arrows indicate proliferative pathways triggered by $\mathrm{nAChRs}$ This activation triggers the MAP kinase pathway, leading to DNA synthesis. Sustained mitogenic signaling induces to S-phase entry. Black arrows indicate nAChR survival and proliferation pathways triggered by intracellular calcium increases involving indirect activation of $\beta$-adrenergic receptor signaling, which in turn, induces activation of epidermal growth factor (EGF) receptor leading to the cascade indicated by blue arrows. $\alpha 7 \mathrm{nAChR}$ and heteromeric $\alpha-\beta \mathrm{nAChRs}$ are activated by their agonists. Influx of $\mathrm{Ca}^{2+}$ and other cations through the $n A C h R s$ and voltage-gated $\mathrm{Ca}^{2+}$ channels trigger the release of adrenaline and noradrenalin. Adenylyl cyclase activation downstream of $\beta$-adrenergic receptors induce the cyclic AMP-protein kinase A (PKA)-CREB (cAMP response element-binding protein) pathway, transactivates epidermal growth factor receptor (EGFR) and induces the release of EGF, and perhaps another growth factors. The responsiveness of this pathway is enhanced by $\alpha 7$ $\mathrm{nAChR}$-mediated activation of Ras through $\beta$-arrestin-dependent SRC signaling. In turn, the EGFR activates the Akt pathway and its downstream effectors, $X$-linked inhibitor of apoptosis protein (XIAP)-survivin and nuclear factor- $\kappa B(N F-\kappa B)$.

responsible for the anti-apoptotic effects of nicotine. The $\alpha 7$ and the $\alpha 4 \beta 2$ subtypes may play the most significant role in the central nervous system [180,182,183]. Data from some laboratories indicate that phosphorylation of ERK1/2 in nicotine-treated neurons can be specifically prevented by pre-exposure to the $\alpha 7$ blocker $\alpha$-bugarotoxin, but not dihydro- $\beta$-erythroidine (an antagonist of the $\beta 2$ subunit) $[172,178,181]$, indicating an important role for the $\alpha 7$ receptor in nicotine-mediated neuroprotection. On the other hand, studies in tumor and tumoral stem cells have implicated the dihydro- $\beta$-erythroidinesensitive $\alpha 3$ and $\alpha 4$ receptors. This finding implies that the proliferative effects (mediated by $\alpha 7 \mathrm{nAChR}$ ) and prosurvival effects (mediated by $\alpha 3$ or $\alpha 4 \mathrm{nAChR}$ ) of nicotine 
are mediated by two distinct classes of receptors $[8,13,162,171]$. These data demonstrate that during differentiation there are changes in nAChR activity and function. This could be due to $\beta$-adrenergic receptor activation through $\alpha 7 \mathrm{nAChR}$, which has been found to mediate the anti-apoptotic effects of nicotine in some cell lines [184186] (for a more detailed discussion see [168]). Such discrepancies can be partially explained by the pleiotropic nature of nAChR subunit inhibitors. It is also possible that the anti-apoptotic effects of nicotine are mediated by different nAChR subunits in a tissue-specific manner. These possibilities underscore the need for further studies to identify the nAChR subunits responsible for the antiapoptotic effects of nicotine.

It is known that ERK1/2 signaling can participate in the neuroprotective effects of nicotine through a variety of different mechanisms. Previous reports showed that ERK2 can increase expression of bcl-2 and inhibit apoptosis [187]. In addition, the neuroprotective effects of ERK1 and ERK2 may be related to activation of a variety of transcription factors, which in turn can regulate transcription of neurotrophic factors, leading to overexpression of "survival" genes and enhanced neuronal viability. Among the transcription factors that are involved in the ERK-medi-

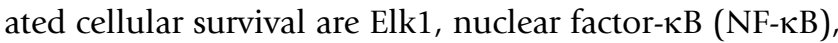
and CAMP response element (CRE)-binding factor (CREB) [188-190]. A role for NF-kB in neuronal survival has been suggested [191]. In addition, recent evidence indicates that CREB has a crucial role in regulation of cell viability [192], as it is required to induce transcription of BDNF [193]. Elk1 functions as a nuclear transcriptional activator through the interaction with the serum response element (SRE), which is present in the promoter of many immediate early genes [194]. Among others, Elk1 is involved in regulation of expression of FGF-2 [195,196].

\section{Signaling pathways of mAChRs involved in proliferation and neuronal differentiation}

Previous studies have demonstrated that proliferation and differentiation of neuronal precursor cells can be modulated by mAChR signaling $[8,13,197,198]$. The mechanism involved initially amplifies mAChR and nAChR signals, inducing calcium influx, which in turn activates MAPK-dependent pathways $[8,13,199]$. Transient calcium increases induced by ACh independently of MAPk activation has been shown to be necessary for differentiation and proliferation, as muscarinic antagonists and calcium chelating agents block these effects (Figures 3 and 4) $[8,13]$.

Activation of $\mathrm{M} 2$ and $\mathrm{M} 3$ receptors has been shown to increase proliferation of tumoral cells in a dose-dependent manner. Cellular proliferation induced by the M3 subtype is mediated by production of inositol triphosphate, $[8,66]$ and nitric oxide [for a review see $[200]]$, while the effects of the M2 subtype were dependent on concomitant activation of $\mathrm{M} 1$, promoting the release of $\mathrm{E} 2$ prostaglandin and arginase catabolism. These events are related to tumoral cell growth [66], and inhibition of caspases $[79,83]$.

In murine mammary adenocarcionoma cells, the M3 subtype is the most highly expressed muscarinic receptor. Stimulation of M3 receptors activates adenilate cyclase, phospholipase $\mathrm{A}_{2}\left(\mathrm{PLA}_{2}\right)$, IP3 and diacylglicerol (DAG) through PLC [201]. Each of these molecules in turn activates different pathways. DAG activates protein kinase $\mathrm{C}$ (PKC), while IP3 induces release of calcium from intracellular stores. It is known that both pathways regulate MAPK and ERK signaling. Free intracellular $\mathrm{Ca}^{2+}$ can modulate MAPK/ERK either through $\mathrm{Ca}^{2+}$-dependent protein tyrosine kinase (PYK2) [202] or by $\mathrm{Ca}^{2+} /$ calmodulin kinase $\left(\mathrm{Ca}^{2+} / \mathrm{CaM}\right)$ [203]. PKC isoforms are also known to regulate MAPK/ERK through Raf-1 [204] or through transactivation of the epidermal growth factor receptor (EGFR) mediated by the Src/PYK2 complex (Figures 2 and 3 ) [205].

Recent evidence suggests that activation of MAPK/ERK through GPCRs occurs through PKC-dependent and independent mechanisms, depending on the receptor activated and on the cell type $[206,207]$. It is known that activation of MAPK/ERK GPCR agonists mediate cell proliferation $[55,208]$, and that pathways involving cholinergic receptors seem to depend on the cell growth $[8,74]$.

Stimulation of mAChRs promotes an increase in $\left[\mathrm{Ca}^{2+}\right]_{\mathrm{i}}$ and induces phosphorylation of MAPK/ERK in MCF-7 human breast cancer cells [105]. Activation of this pathway increases protein synthesis and cell proliferation through MAPK kinase, besides inducing DNA synthesis in neuronal progenitor cells during early neurogenesis [209]. Inhibition of PLC or incubation of cells in a calcium free medium did not alter MAPK/ERK phosphorylation; however, this phosphorylation can also be induced through treatment with phorbol 12-myristate acetate (PMA), a PKC activator. Activation of MAPK/ERK was not affected by PKC modulation or by its inhibition. Interestingly, phosphorylation of MAPK/ERK by mAChRs could be blocked by a PKC- $\zeta$ (a miroystoilated pseudo substrate of PKC) inhibitor and by high doses of staurosporine (a relatively non-selective protein kinase inhibitor). This pathway involves PI3-K and tyrosine kinases, such as Src, and Erk 1/2 [105,209]. Cells in the neuroepithelial ventricular zone of the embryonic rat cortex also express the M2 receptor. The presence of $\mathrm{M} 2$ induces cell proliferation and accelerates neuronal differentiation.

Adrenergic receptors can transform fibroblasts when actively mutated [210]. Interestingly, transformation by mAChRs was ligand-dependent [211]. Furthermore, some 


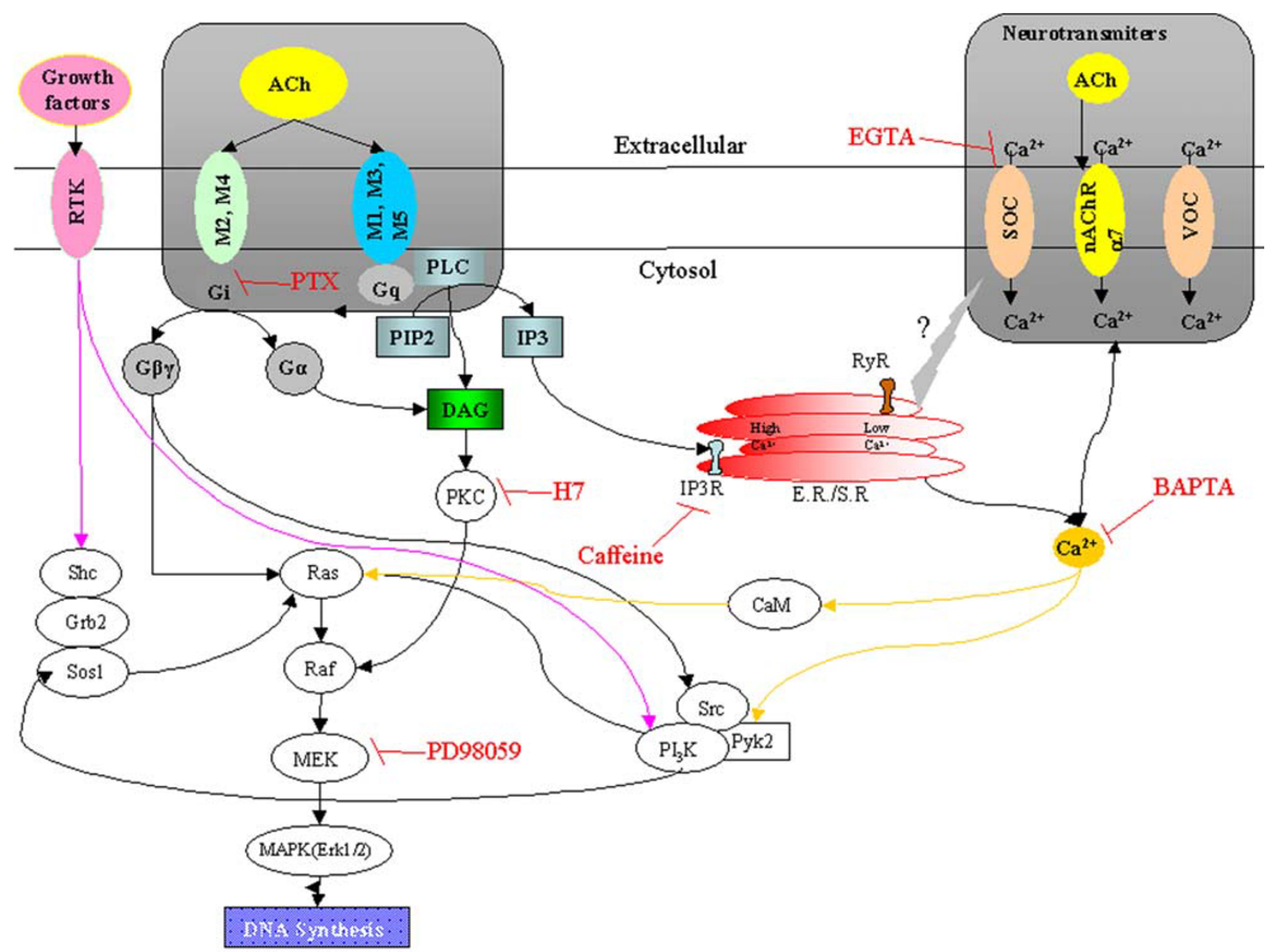

Figure 3

Muscarinic and nicotinic receptor-coupled signal transduction pathways mediating MAPK activity and proliferation. Both Erkl/2 activity and cell proliferation are activated by cholinergic (ACh) stimulation of mAChRs. ACh binds to M3, leading to a $\mathrm{G}_{\mathrm{q}}$-protein-mediated activation of PLC, which hydrolyses PIP2 to IP3 and DAG, subsequently mobilizing Ca2+ from organellar stores, leading to activation of PKC. Both ACh-induced MAPK activity and proliferation are reduced by the PKC inhibitor H7, indicating that PKC activity appears to be one of the upstream events critical to MAPK activation. mAChR stimulation induces increases in $\left[\mathrm{Ca}^{2+}\right]_{\mathrm{i}}$ via both $\mathrm{Ca}^{2+}$ influx and mobilization from intracellular stores. Muscarinic stimulation of MAPK activity and proliferation is prevented both by BAPTA-AM and EGTA, demonstrating that elevation of [Ca $\left.{ }^{2+}\right]_{i}$ is essential, and may stimulate Pyk2 phosphorylation and activate the MAPK. Muscarinic stimulation of MAPK activity is effectively eliminated by the MAPK kinase (MEK) inhibitor PD98059. M2 and M4 may provide parallel pathways to MAPK activation via pertussis toxin-sensitive $\mathrm{G}_{\mathrm{i}}$-proteins and $\beta \gamma$ subunits. ERKI/II (MAPK) can serve as a convergence site for multiple extracellular signals known to induce plasticity in mature neurons. The best documented activation of the MAPK cascade occurs via ligand binding to RTK. Activation of RTK recruits the Shc-Grb2-SOSI complex, which in turn activates Ras. Ras induces MAPK activation via an evolutionarily conserved pathway, which includes Raf, MEK (MAPKK), and ERKI/II (MAPK) (MAPK cascade). ERKI/ II is known to have both cytoplasmic and nuclear targets and can translocate to the nucleus to modulate transcription in neurons. The block of proliferation induction by the MEK inhibitor PD98059 suggests that MAPK plays a role in the induction phase of proliferation. MAPK can also be activated in neural progenitor cells via $\mathrm{nAChRs}$ which increase $\left[\mathrm{Ca}^{2+}\right]_{\mathrm{i}}$, and may modulate the MAPK cascade via activation of a $\mathrm{Ca}^{2+}$-dependent tyrosine kinase (PYK2) or calmodulin (CaM). 


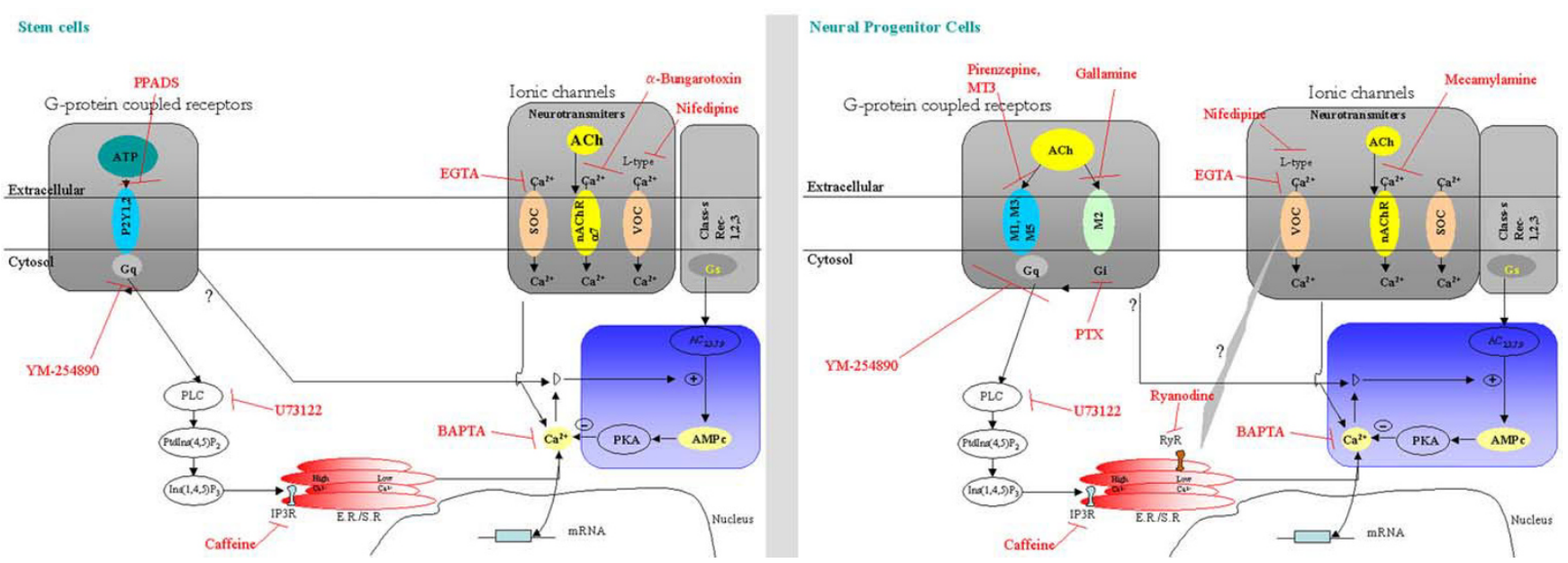

\section{Figure 4}

Calcium signaling pathways in stem cells and neural progenitor cells. Left panel represents a embryonic or adult stem cells and right panel the neuronal progenitor cells. $\mathrm{Ca}^{2+}$ signaling depends on the increase of the intracellular $\mathrm{Ca}^{2+}$ levels $\left[\mathrm{Ca}^{2+}\right]_{\mathrm{i}}$, derived from extracellular calcium $\left(\mathrm{Ca}^{2+}\right)$ o sources or intracellular stores of the endoplasmic reticulum $\left(\mathrm{ER} \mathrm{Ca}{ }^{2+}\right)$. It can enter through calcium channels operated by voltage (voltage-operated $\mathrm{Ca}^{2+}$ channels, VOCCs) in excitable cells such as neurons and muscular cells, or through calcium channels operated by receptors (receptor-operated $\mathrm{Ca}^{2+}$ channels, $\mathrm{ROCs}$ ) in response to neurotransmitters. SOC's (store-operated $\mathrm{Ca}^{2+}$ channels, SOCs), open when internal $\mathrm{Ca}^{2+}$ stores are empty, and are generally present in non-excitable cells. Calcium from the ER is released by two types of channels, Inositol I,4,5-trisphosphate (IP3) channels and ryanodine channels. The first is present in both neural progenitor and stem cells, while the latter is expressed only in nural progenitor cells. IP3 is generated by the action of the enzyme PLC in phosphatidylinositol 4,5-bisphosphate (PIP2). IP3 acts on receptors in the endoplasmic reticulum, promoting the release of $\mathrm{Ca}^{2+}$ from ER stores. IP3PIP2.

viruses encode constitutively active GPCRs linked to cell proliferation (for a review see $[212,213]$ ), suggesting that signals initiated by GPCRs can be mitogenic.

MAPKs target numerous cellular proteins and transcription factors involved in cell growth and differentiation [214-216]. It is known that GPCRs activate MAPK through the small GTP-binding protein, p21Ras [217]. How p21Ras is activated is still controversial; however, it is likely that transactivation of EGFR upon stimulation of GPCRs participates in p21Ras activation $[218,219]$. Indeed, several types of GPCRs including thrombin, endothelin, and angiotensin II receptors have been shown to transactivate EGFR, leading to MAPK activation $[220,221]$.

The vast majority of the currently described pathways leading to ERK stimulation have been considered as linear. While GPCRs coupled with Gi-protein activate the p21Ras-ERK pathway through the $\beta \gamma$ subunit and PI-3 kinase, GPCRs with Gq-protein activate it in a PKCdependent manner [222,223]. However, Blaukat et al. [223] recently showed that GPCRs mediate ERK activation through cooperation of Gi and Gq, suggesting that multiple G-proteins could act in concert to attain full activation of p21Ras-ERK pathway. Muscarinic receptors in many cells have been shown to activate ERK by carbachol, and this is not altered by treatment with pertussis toxin, indicating that Gq-, but not Gi-protein, may be involved in ERK activation [61,224-229]. Muscarinic receptor activation by carbachol rapidly and transiently stimulates ERK1/2 phosphorylation in many cells in a time- and dose-dependent manner [61,226-229], as observed in various cell lines $[230,231]$. It was shown that the inhibition of PLC led to a total blockade of $\mathrm{Ca}^{2+}$ mobilization induced by AChRs agonists $[13,232]$. A role of $\mathrm{Ca}^{2+}$ in this pathway is also supported by the finding that an increase in intracellular $\mathrm{Ca}^{2+}$ caused by thapsigargin $[8,13,105,233]$ is sufficient to induce ERK phosphorylation up to levels similar to those induced by AChRs agonists. The mechanisms by which intracellular $\mathrm{Ca}^{2+}$ stimulates the phosphorylation of ERK1/2 are complex and appear to be dependent on the nature of $\mathrm{mAChR}$ subtype coupling to heterotrimeric $G$ proteins. Intracellular $\mathrm{Ca}^{2+}$ can modulate the MAPK cascade, via activation of the monomeric G-protein p21 ras [234-236], through two convergent mechanisms; one through the calcium-dependent tyrosine kinase (PYK2) and the other mediated by calmodulin $[228,231,237]$. In $\mathrm{T}_{84}$ colon epithelial cells, which express endogenous M3 mAChR subtypes, increases in $\left[\mathrm{Ca}^{2+}\right]_{\mathrm{i}}$ in response to carbachol activate signaling mechanisms involving calmodulin-, PYK2-, and p60 ${ }^{\text {src }}$-mediated transactivation of the EGF receptor [238]. Besides $\mathrm{Ca}^{2+}$, the other downstream pathway induced 
after PLC activation is the PKC transduction cascade. It was demonstrated that the direct activation of PKC, by the phorbol ester PMA, was sufficient to increase the phosphorylation of ERK1/2 reaching levels similar to those induced by carbachol in FRT cells [105]. However, the carbachol-induced ERK1/2 phosphorylation was not mediated by PKC. These data indicate that the mAChR-induced ERK phosphorylation is mediated by a $\mathrm{Ca}^{2+}$-dependent but PKC-independent mechanism.

Although some data suggest that intracellular $\mathrm{Ca}^{2+}$ partly mediates the activation of ERK1 and ERK2, other intracellular signaling pathways may be involved in the MAPK/ ERK activation in undifferentiated cells. Activation of MAPK by GPCRs, including mAChRs, involves phosphorylation of one or more proteins, such as $\mathrm{p} 125^{\mathrm{FAK}}$, p130 cas, or paxillin [239]. Moreover, the Src family of protein tyrosine kinases has been implicated in mAChR-induced ERK activation in different cell lines [240-242]. Further studies are needed to determine the connection between activation of these protein tyrosine kinases and the downstream effects of mAChR after $\mathrm{G}$ protein activation.

It has been suggested that carbachol's effects on ERK1 and ERK2 phosphorylation were probably mediated through the activation of protein tyrosine kinases. Furthermore, it has been demonstrated that carbachol-induced ERK activation is dependent on the activity of cytoplasmatic Srclike tyrosine kinase family, since pharmacological inhibition of the Src family of tyrosine kinases with specific PP2 blocks the carbachol-induced MAPK/ERK activation [55]. The Src family of tyrosine kinases has been implicated in the ERK activation by various GPCRs agonists. Recent data suggests that activation of Src tyrosine kinases may lead to the phosphorylation of the adaptor protein Shc and the recruitment of Grb/Sos complex to the plasma membrane, resulting in the activation of the ERK pathway $[223,243]$.

\section{Signaling pathways of nAChRs involved in proliferation and neuronal differentiation}

Previous reports have shown that nAChRs are expressed in non-neuronal cells within the nervous system [244,245], embryonic stem cells [8,13], neural stem cells [197], and embryonic tissues [246].

Microglia express $\alpha 7$ nAChRs [247], and stimulation of $\alpha 7$ nAChRs promotes anti-inflammatory pathways and blunts the response of migroglia to lipopolysaccaride [247], suggesting that nAChRs may have a role in controlling localized brain inflammation. Nicotinic receptors are also expressed on O2A oligodendrocyte precursors, but are not detectable after induction of differentiation, indicating that nAChR expression is developmentally controlled in these cells [248]. Although the physiological functions of nAChRs in O2A oligodendrocyte precursors are not understood, data suggest that activation of nAChRs might control migration, survival and differentiation in these cells [248].

It has been found that in non-neuronal tissues nicotine induces the secretion of growth factors like bFGF, TGF- $\alpha$, VEGF, and PDGF [249] Nicotine also upregulates expression of the calpain family of proteins [250] as well as COX-2 and VEGFR-2 [251], activating the Raf/MAPK kinase/ERK pathway [252]. Since nAChRs do not have intrinsic tyrosine kinase activity [22], the molecular mechanisms underlying its effects on proliferation remain unclear. It was demonstrated that nicotine-mediated induction of cell proliferation involves recruitment of $\beta$ arrestin, which facilitates the activation of Src. This in turn leads to binding of Raf-1 kinase to $\mathrm{Rb}$, leading to cell cycle entry [253]. Dasgupta and coworkers demonstrated that human non-small cell lung cancer (NSCLC) tumor tissues had high levels of Rb-Raf- 1 complexes in tumors relative to adjacent normal lung tissue, suggesting that perhaps the Rb-Raf- 1 pathway contributes to the genesis of these tumors. Furthermore, chromatin IP (ChIP) analysis of human NSCLC tumor samples demonstrated increased recruitment of E2F1 and Raf-1 to proliferative promoters like cdc 6 and cdc25A. These results suggest that binding of $\beta$-arrestin to nAChRs is an early and critical event in the initiation of nicotine-induced mitogenesis. The subsequent steps resemble growth factor-induced cell proliferation, as they include activation of Src, association of $\mathrm{Rb}$ to Raf-1, inactivation of $\mathrm{Rb}$, and enhanced recruitment of E2F1 and Raf-1 to promoters of genes that induce proliferation [253]. These events are likely to contribute to the growth and progression of tumoral cells.

\section{Therapeutic uses of cholinergic receptor modulators in stem cell specification In vivo proliferation, differentiation, and genetic modification of neural stem cell progeny}

As previously demonstrated $[8,13]$, AChRs have different roles on proliferation in embryonic and neural stem cells. In embryonic cells, nAChRs decrease proliferation. Conversely, neural stem cells and their progeny can be induced to proliferate in vivo by administering $\alpha 7$ agonists [13]. To initiate neuronal differentiation, agonists for the $\mathrm{G \alpha}_{\mathrm{i}}$-coupled mAChRs, such as the M2 subtype, could be used for treatment. These pharmacological agents include any substance that acts through AChR activation or through pathways activated by them. The examples described here to modulate proliferation, differentiation, and genetic modification of neural stem cells in vitro can be adapted to in vivo techniques. Such in vivo manipulation and modification of these cells allows cells lost due to injury or disease to be endogenously replaced. This would abolish the need for transplanting foreign cells into 
a patient. Additionally, cells can be modified or genetically engineered in vivo so that they express various biological agents useful in the treatment of neurological disorders. However, fine control of muscarinic signaling requires compounds that selectively modulate specific muscarinic receptor subtypes. Unfortunately, such drugs have not been discovered yet. M1 muscarinic agonists such as arecoline have also been found to be weak agonists of M2 and M3 subtypes, and are not very effective in treating cognitive impairment, most likely because of dose-limiting side effects $[254,255]$. Selective muscarinic agonists for M5 and M2 subtypes could be used both as pharmacological tools and as therapeutic agents [8], as M5 and M2 mediate most of the muscarinic $\left[\mathrm{Ca}^{2+}\right]_{\mathrm{i}^{-}}$ response and seem to control proliferation and differentiation induction, respectively.

Treatment with nicotinic receptor agonists also has therapeutic potential, similarly to muscarinic agonists. However, $\mathrm{nAChR}$ agonists which bind the same site as ACh are not a viable solution, for ACh not only activates, but also blocks receptor activity through desensitization [256] and uncompetitive blockade [for review see [257]]. Furthermore, prolonged activation appears to induce a long-lasting inactivation. Therefore, agonists of ACh may reduce or enhance receptor activation. In nAChRs, desensitization generally limits the duration of current during agonist application [258]. However, positive allosteric modulators can enhance the efficacy of agonists at nicotinic receptors. It is believed that such compounds would be useful for treatment of conditions associated with decreased nicotinic transmission. In a therapeutic setting, these compounds could restore normal interneuronal communication without affecting the temporal profile of activation. In addition, they would not produce long-term inactivation, contrary to prolonged application of an agonist.

A naturally existing allosteric modulator of nicotinic transmission is the CGRP (Calcitonin Gene Related Peptide) neuropeptide $[259,260]$. Previous reports show that CGRP blocks nAChRs competitively. It is noteworthy to point out that this effect is not mediated by conventional G-protein-coupling [261], as it was demonstrated that this peptide's activity is contained within the 1-7 N-terminal fragment. Similarly to the native CGRP, CGRP 1-7 shows a rapidly developing, competitive antagonism which is readily reversible after washout [261]. Intriguingly, some CGRP fragments quickly and reversibly enhance responses mediated by the activation of native neuronal nAChRs [262]. Mutant versions of the CGRP peptide fragment can be used as neuronal nAChRs enhancers, as in the absence of nAChR activation these peptides were inactive [262].
The CGRP 1-6 peptide did not modify the muscle-type nicotinic receptor responses, indicating its selectivity for neuronal receptors. This finding suggests that certain peptide derivatives shorter than CGRP 1-7 exert an unusual action, involving an apparently competitive modulation of the agonist-binding site. CGRP $1-6$ and its derivatives may be used for the treatment of symptoms of neurological diseases associated with functional deficits of nAChRs and may be used as stem cell neuronal differentiation enhancers.

Interestingly, nicotine has been shown to protect cells from apoptosis induced by anticancer drugs. The acquisition of drug resistance is a considerable challenge in cancer therapy, and nAChR antagonists could be potentially used in combination with established chemotherapeutic drugs to enhance the therapeutic response to chemotherapy. The bioactivity of nAChR antagonists, however, has yet to be tested in animal models. Carefully designed animal studies are essential to investigate the potential side effects of nAChR antagonists on the brain, central nervous system, immune cells and muscle cells, all of which express high levels of nicotinic receptors.

The study of the roles of nAChRs in development and progression of cancer and stem cells differentiation provides novel opportunities for the prevention and therapy of cancer and degenerative disorders. However, it is important to consider that vital cell and organ functions are regulated by these receptors. Antagonists for $\alpha 7 \mathrm{nAChR}$ may successfully block cancer cells and promote proliferation of stem cells without cytotoxicity to normal control cells in vitro, but in vivo it would induce adverse effects on the control of inflammatory reactions and the regulation of respiratory and cardiovascular functions, and may also lead to psychiatric symptoms $[22,168,263]$.

Blockers of $\mathrm{Ca}^{2+}$ channels are known for their anti-proliferative properties and might be an alternative because they can desensitize the hyperactive $\alpha 7 \mathrm{nAChR}$ (Figure 1). However, experimental findings appear to be divergent and depend on the cell type and mode of administration used. Among the calcium channel inhibitors, L- and Ttype calcium blockers, were reported to inhibit neuronal differentiation [12,264-266], but have limited effect on other cell types. Mibefradil, a selective blocker of T-type channels, has significant anti-proliferative action in various cell types in vitro as well as in vivo $[267,268]$. The nonselective calcium blocker amlodipine is also a very effective protector of neuronal cells [269-271]. Calcium channel blockers induce a rapid decrease in intracellular $\mathrm{Ca}^{2+}$, even in cells lacking depolarization-induced calcium flux $[272,273]$. These observations suggest that amlodipine inhibits cell proliferation through intracellular signaling 
pathways rather than through inhibition of $\mathrm{Ca}^{2+}$ entry channels.

Another possible pharmacological treatment is the use of SluRP1, a drug that reduces the responsiveness of $\alpha 7 n A C h R$ to agonists. SluRP1 may have an effect similar to that of voltage-gated $\mathrm{Ca}^{2+}$ channels blockers [274]. However, any attempt to prevent or treat cancer by targeting nAChRs must be based on the identification of molecular markers. The goal of this strategy is the restoration of balance between stimulatory and inhibitory signaling and not complete blockade of a given pathway.

Nicotinic signaling in non-neuronal cells has huge implications for cell fate and survival. Research in nAChR signaling networks will be especially relevant to stem cell production in a large scale and cancer treatment. Future studies will need to define both the function of different nAChR subtypes in non-neuronal cells and the downstream signaling pathways that underlie the proliferative and anti-apoptotic activities of nicotine.

Similarly to nicotinic signaling, the mechanisms that underlie the pro-mitogenic effects of muscarinic receptor stimulation have not yet been studied in detail. However, several intracellular signaling pathways that regulate the synergistic mitogenic interaction of other GPCR agonists with growth factors in neural progenitor cells have been identified (Figures 1 and 3). These pathways are not the same for every GPCR agonist The GPCRs M1 and M3 increase EGF-induced proliferation through a pathway involving $\mathrm{G} \beta \gamma$, phosphatidylinositol-3-kinase, Akt and PKC $[105,238]$. Muscarinic stimulation of MAPK activity and proliferation is prevented both by the intracellular $\mathrm{Ca}^{2+}$ chelator BAPTA-AM and by a reduction in extracellular $\mathrm{Ca}^{2+}$ with EGTA. This suggests that increases in intracellular calcium are essential, and may stimulate Pyk2 phosphorylation and then activate the MAPK signaling pathway [238]. PKC also regulates p42/p44 MAP kinase activation by muscarinic receptor agonists in neuronal progenitor cells [55].

\section{Concluding remarks}

There is a growing body of evidence indicating that nicotinic and muscarinic receptors play important roles in stem cell differentiation and physiology. The disruption of developmental patterns and of normal function is often correlated with pathological conditions. Therefore, the controlled manipulation of ACh function may lead to novel therapies. Strikingly, studies have revealed that drugs currently used to treat disorders such as Alzheimer's disease and depression, increase adult neurogenesis, which may be the mechanism mediating the activity of these drugs. However, some of these studies are controversial, and remain to be confirmed. Hence, the role of neu- rogenesis in treating central nervous system disorders, as well as the effects of drugs on embryonic and adult stem cells' neuronal differentiation remain areas of active research. Discriminating specific contributions of nAChR and mAChR signaling for the control of phenotypic features as specialized structural and functional behaviors is a great challenge and has undeniable potential regarding future applications.

\section{Competing interests}

The authors declare that they have no competing interests.

\section{Authors' contributions}

RRR and AA wrote the manuscript. The authors read and approved the final manuscript.

\section{Acknowledgements}

This work was supported by Instituto do Milenio/CNPq-MCT and Instituto Nacional de Ciência e Tecnologia de Nanomateriais de Carbono, CNPq (Conselho Nacional de Desenvolvimento Científico e Tecnológico), Brazil. R.R.R is grateful for grants from CNPq, and FAPEMIG (Fundação de Amparo à Pesquisa do Estado de Minas Gerais), Brazil. English editing has been performed throughout the text by native English speaker Dra. Elizabeth Speed.

\section{References}

I. Horiuchi Y, Kimura R, Kato N, Fujii T, Seki M, Endo T, Kato T, Kawashima K: Evolutional study on acetylcholine expression. Life Sci 2003, 72: I745-I756.

2. Grando SA: Biological functions of keratinocyte cholinergic receptors. J Investig Dermatol Symp Proc 1997, 2:4 I-48.

3. Wessler I, Kirkpatrick CJ, Racke K: The cholinergic 'pitfall': acetylcholine, a universal cell molecule in biological systems, including humans. Clin Exp Pharmacol Physiol 1999, 26:198-205.

4. Kawashima K, Fujii T: Extraneuronal cholinergic system in lymphocytes. Pharmacol Ther 2000, 86:29-48.

5. Wessler I, Reinheimer T, Kilbinger H, Bittinger F, Kirkpatrick C], Saloga J, Knop J: Increased acetylcholine levels in skin biopsies of patients with atopic dermatitis. Life Sci 2003, 72:2169-2 I72.

6. Tobin AB, Budd DC: The anti-apoptotic response of the $\mathbf{G q} / \mathbf{I}$ I coupled muscarinic receptor family. Biochem Soc Trans 2003, 3 I: I | 82- I I85.

7. Kawashima K, Fujii T: Expression of non-neuronal acetylcholine in lymphocytes and its contribution to the regulation of immune function. Front Biosci 2004, 9:2063-2085.

8. Resende RR, Alves AS, Britto LR, Ulrich H: Role of acetylcholine receptors in proliferation and differentiation of $P 19$ embryonal carcinoma cells. Exp Cell Res 2008, 3 | 4: |429-|443.

9. Williams BP, Milligan CJ, Street M, Hornby FM, Deuchars J, Buckley $\mathrm{NJ}$ : Transcription of the $\mathrm{MI}$ muscarinic receptor gene in neurons and neuronal progenitors of the embryonic rat forebrain. J Neurochem 2004, 88:70-77.

10. Wessler I, Kirkpatrick C]: Acetylcholine beyond neurons: the non-neuronal cholinergic system in humans. $\mathrm{Br} J$ Pharmacol 2008, I54:|558-I57I.

II. Martins AH, Resende RR, Majumder P, Faria M, Casarini DE, Tarnok $A$, Colli W, Pesquero JB, Ulrich $\mathrm{H}$ : Neuronal differentiation of PI 9 embryonal carcinoma cells modulates kinin B2 receptor gene expression and function. I Biol Chem 2005, 280:19576-19586.

12. Resende RR, Majumder P, Gomes KN, Britto LR, Ulrich H: PI9 embryonal carcinoma cells as in vitro model for studying purinergic receptor expression and modulation of $\mathbf{N}$-methylD-aspartate-glutamate and acetylcholine receptors during neuronal differentiation. Neuroscience 2007, I46: I I69-I I8I.

13. Resende RR, Gomes KN, Adhikari A, Britto LR, Ulrich H: Mechanism of acetylcholine-induced calcium signaling during neu- 
ronal differentiation of PI9 embryonal carcinoma cells in vitro. Cell Calcium 2008, 43:107-I2I.

14. Buznikov GA, Shmukler YB, Lauder JM: From oocyte to neuron: do neurotransmitters function in the same way throughout development? Cell Mol Neurobiol 1996, 16:537-559.

15. Levitt P, Harvey JA, Friedman E, Simansky K, Murphy EH: New evidence for neurotransmitter influences on brain development. Trends Neurosci 1997, 20:269-274.

16. Bignami F, Bevilacqua P, Biagioni S, De Jaco A, Casamenti F, Felsani A, Augusti-Tocco G: Cellular acetylcholine content and neuronal differentiation. J Neurochem 1997, 69:1374-1381.

17. Schuller HM: Cell type specific, receptor-mediated modulation of growth kinetics in human lung cancer cell lines by nicotine and tobacco-related nitrosamines. Biochem Pharmacol 1989, 38:3439-3442.

18. Maneckjee R, Minna JD: Opioid and nicotine receptors affect growth regulation of human lung cancer cell lines. Proc Natl Acad Sci USA 1990, 87:3294-3298.

19. Lindstrom JM: Acetylcholine receptors and myasthenia. Muscle Nerve 2000, 23:453-477.

20. Changeux J, Edelstein SJ: Allosteric mechanisms in normal and pathological nicotinic acetylcholine receptors. Curr Opin Neurobiol 200I, I I:369-377.

21. Hogg RC, Raggenbass M, Bertrand D: Nicotinic acetylcholine receptors: from structure to brain function. Rev Physiol Biochem Pharmacol 2003, 147:1-46.

22. Gotti C, Clementi F: Neuronal nicotinic receptors: from structure to pathology. Prog Neurobiol 2004, 74:363-396.

23. McGehee DS, Role LW: Presynaptic ionotropic receptors. Curr Opin Neurobiol 1996, 6:342-349.

24. Koh DC, Armugam A, Jeyaseelan K: Snake venom components and their applications in biomedicine. Cell Mol Life Sci 2006 , 63:3030-304I.

25. Portugal GS, Gould T]: Genetic variability in nicotinic acetylcholine receptors and nicotine addiction: converging evidence from human and animal research. Behav Brain Res 2008, 193:I-16.

26. Changeux JP, Edelstein SJ: Allosteric receptors after $\mathbf{3 0}$ years. Neuron 1998, 21:959-980.

27. Seguela P, Wadiche J, Dineley-Miller K, Dani JA, Patrick JW: Molecular cloning, functional properties, and distribution of rat brain alpha 7: a nicotinic cation channel highly permeable to calcium. J Neurosci 1993, 13:596-604.

28. Broide RS, Leslie FM: The alpha7 nicotinic acetylcholine receptor in neuronal plasticity. Mol Neurobiol 1999, 20:1-16.

29. Forster GL, Yeomans JS, Takeuchi J, Blaha CD: M5 muscarinic receptors are required for prolonged accumbal dopamine release after electrical stimulation of the pons in mice. J Neurosci 2002, 22:RCI 90.

30. Yeomans J, Forster G, Blaha C: M5 muscarinic receptors are needed for slow activation of dopamine neurons and for rewarding brain stimulation. Life Sci 200I, 68:2449-2456.

3I. Basile AS, Fedorova I, Zapata A, Liu X, Shippenberg T, Duttaroy A, Yamada M, Wess J: Deletion of the M5 muscarinic acetylcholine receptor attenuates morphine reinforcement and withdrawal but not morphine analgesia. Proc Natl Acad Sci USA 2002, 99: II 452-1। 457

32. Wang H, Ng K, Hayes D, Gao X, Forster G, Blaha C, Yeomans J: Decreased amphetamine-induced locomotion and improved latent inhibition in mice mutant for the M5 muscarinic receptor gene found in the human $15 \mathrm{q}$ schizophrenia region. Neuropsychopharmacology 2004, 29:2 I 26-2I39.

33. Tzavara ET, Bymaster FP, Davis RJ, Wade MR, Perry KW, Wess J, McKinzie DL, Felder C, Nomikos GG: M4 muscarinic receptors regulate the dynamics of cholinergic and dopaminergic neurotransmission: relevance to the pathophysiology and treatment of related CNS pathologies. Faseb / 2004, 18:1410-14I2.

34. Di Cara B, Panayi F, Gobert A, Dekeyne A, Sicard D, De Groote L, Millan MJ: Activation of dopamine DI receptors enhances cholinergic transmission and social cognition: a parallel dialysis and behavioural study in rats. Int $J$ Neuropsychopharmacol 2007, 10:383-399.

35. Hegde SS, Mammen M, Jasper JR: Antimuscarinics for the treatment of overactive bladder: current options and emerging therapies. Curr Opin Investig Drugs 2004, 5:40-49.
36. Racke K, Matthiesen S: The airway cholinergic system: physiology and pharmacology. Pulm Pharmacol Ther 2004, 17:18I-198.

37. Keam SJ, Keating GM: Tiotropium bromide. Treat Respir Med 2004, 3:247-268.

38. Terry AV Jr, Buccafusco Jj: The cholinergic hypothesis of age and Alzheimer's disease-related cognitive deficits: recent challenges and their implications for novel drug development. J Pharmacol Exp Ther 2003, 306:821-827.

39. Bartus RT: On neurodegenerative diseases, models, and treatment strategies: lessons learned and lessons forgotten a generation following the cholinergic hypothesis. Exp Neurol 2000, 163:495-529.

40. Fox RI: Sjogren's syndrome: evolving therapies. Expert Opin Investig Drugs 2003, 1 2:247-254.

41. Roman GC: Cholinergic dysfunction in vascular dementia. Curr Psychiatry Rep 2005, 7:18-26.

42. Felder CC, Bymaster FP, Ward J, DeLapp N: Therapeutic opportunities for muscarinic receptors in the central nervous system. J Med Chem 2000, 43:4333-4353.

43. Birdsall NJ, Lazareno S, Popham A, Saldanha J: Multiple allosteric sites on muscarinic receptors. Life Sci 200I, 68:25I7-2524.

44. Eglen RM, Choppin A, Watson N: Therapeutic opportunities from muscarinic receptor research. Trends Pharmacol Sci 200I, 22:409-4I4.

45. Matsui M, Yamada S, Oki T, Manabe T, Taketo MM, Ehlert F): Functional analysis of muscarinic acetylcholine receptors using knockout mice. Life Sci 2004, 75:297I-298I.

46. Slotkin TA, Cousins MM, Seidler FJ: Administration of nicotine to adolescent rats evokes regionally selective upregulation of CNS alpha 7 nicotinic acetylcholine receptors. Brain Res 2004, 1030:159-163.

47. Zoli M, Le Novere N, Hill JA Jr, Changeux JP: Developmental regulation of nicotinic ACh receptor subunit mRNAs in the rat central and peripheral nervous systems. I Neurosci 1995, 15:1912-1939.

48. Aubert I, Cecyre D, Gauthier S, Quirion R: Comparative ontogenic profile of cholinergic markers, including nicotinic and muscarinic receptors, in the rat brain. J Comp Neurol 1996, 369:3I-55.

49. Court JA, Lloyd S, Johnson M, Griffiths M, Birdsall NJ, Piggott MA, Oakley AE, Ince PG, Perry EK, Perry RH: Nicotinic and muscarinic cholinergic receptor binding in the human hippocampal formation during development and aging. Brain Res Dev Brain Res 1997, 101:93-105.

50. Torrao AS, Carmona FM, Lindstrom J, Britto LR: Expression of cholinergic system molecules during development of the chick nervous system. Brain Res Dev Brain Res 2000, I 24:81-92.

5I. Atluri P, Fleck MW, Shen O, Mah SJ, Stadfelt D, Barnes W, Goderie SK, Temple S, Schneider AS: Functional nicotinic acetylcholine receptor expression in stem and progenitor cells of the early embryonic mouse cerebral cortex. Dev Biol 200I, 240:143-156.

52. Oppitz M, Mobus V, Brock S, Drews U: Muscarinic receptors in cell lines from ovarian carcinoma: negative correlation with survival of patients. Gynecol Oncol 2002, 85:159-164.

53. Hoogduijn MJ, Cheng A, Genever PG: Functional Nicotinic and Muscarinic Receptors on Mesenchymal Stem Cells. Stem Cells Dev 2008 in press.

54. Greco SJ, Zhou C, Ye JH, Rameshwar P: An interdisciplinary approach and characterization of neuronal cells transdifferentiated from human mesenchymal stem cells. Stem Cells Dev 2007, 16:8II-826

55. Zhao WQ, Alkon DL, Ma W: c-Src protein tyrosine kinase activity is required for muscarinic receptor-mediated DNA synthesis and neurogenesis via ERKI/2 and c-AMP-responsive element-binding protein signaling in neural precursor cells. J Neurosci Res 2003, 72:334-342.

56. Bernardini N, Levey Al, Augusti-Tocco G: Rat dorsal root ganglia express $\mathrm{m} \mathrm{I-m} 4$ muscarinic receptor proteins. J Peripher Nerv Syst 1999, 4:222-232.

57. Williams CL, Hayes VY, Hummel AM, Tarara JE, Halsey T]: Regulation of E-cadherin-mediated adhesion by muscarinic acetylcholine receptors in small cell lung carcinoma. J Cell Biol I993, 121:643-654.

58. Boss A, Oppitz M, Drews U: Muscarinic cholinergic receptors in the human melanoma cell line SK-Mel 28: modulation of chemotaxis. Clin Exp Dermatol 2005, 30:557-564. 
59. Rimmaudo LE, de la Torre E, Sacerdote de Lustig E, Sales ME: Muscarinic receptors are involved in LMM3 tumor cells proliferation and angiogenesis. Biochem Biophys Res Commun 2005, 334: 1359- 1364

60. Newman MB, Misiuta I, Willing AE, Zigova T, Karl RC, Borlongan CV, Sanberg PR: Tumorigenicity issues of embryonic carcinomaderived stem cells: relevance to surgical trials using NT2 and hNT neural cells. Stem Cells Dev 2005, I 4:29-43.

61. Wu EH, Wong YH: Activation of muscarinic M4 receptor augments NGF-induced pro-survival Akt signaling in PCI 2 cells. Cell Signal 2006, I 8:285-293.

62. Pollett JB, Corsi KA, Weiss KR, Cooper GM, Barry DA, Gharaibeh B, Huard J: Malignant transformation of multipotent musclederived cells by concurrent differentiation signals. Stem Cells 2007, 25:2302-23II.

63. Song P, Sekhon HS, Lu A, Arredondo J, Sauer D, Gravett C, Mark GP, Grando SA, Spindel ER: M3 muscarinic receptor antagonists inhibit small cell lung carcinoma growth and mitogen-activated protein kinase phosphorylation induced by acetylcholine secretion. Cancer Res 2007, 67:3936-3944.

64. Janulis M, Silberman S, Ambegaokar A, Gutkind JS, Schultz RM: Role of mitogen-activated protein kinases and c-Jun/AP-I transactivating activity in the regulation of protease mRNAs and the malignant phenotype in NIH 3 T3 fibroblasts. J Biol Chem 1999, 274:801-813.

65. Blanco M, Robinson MJ: Muscarinic $\mathbf{M} 3$ acetylcholine receptor immunostaining in paraffin-embedded normal and neoplastic prostatic gland tissue. Ann Diagn Pathol 2004, 8:333-336.

66. Espanol AJ, Sales ME: Different muscarinc receptors are involved in the proliferation of murine mammary adenocarcinoma cell lines. Int J Mol Med 2004, I 3:3 I I-3 I 7 .

67. Metzger M, Just L, Boss A, Drews U: Identification and functional characterization of the muscarinic receptor $M 3$ in the human keratinocyte cell line HaCaT. Cells Tissues Organs 2005, I 80:96-105

68. Shin S, Dalton S, Stice SL: Human motor neuron differentiation from human embryonic stem cells. Stem Cells Dev 2005, I 4:266-269.

69. Hoogduijn MJCA, Genever PG: Functional Nicotinic and Muscarinic Receptors on Mesenchymal Stem Cells. Stem Cells and Development 2008.

70. Inoue $M$, Yoshii M: Modulation of ion channels by somatostatin and acetylcholine. Prog Neurobiol 1992, 38:203-230.

7I. van Koppen CJ, Kaiser B: Regulation of muscarinic acetylcholine receptor signaling. Pharmacol Ther 2003, 98:197-220.

72. Williams CL: Muscarinic signaling in carcinoma cells. Life Sci 2003, 72:2173-2182.

73. Gutkind JS, Crespo P, Xu N, Teramoto H, Coso OA: The pathway connecting $\mathbf{m} 2$ receptors to the nucleus involves small GTPbinding proteins acting on divergent MAP kinase cascades. Life Sci 1997, 60:999-1006.

74. Nicke B, Detjen K, Logsdon CD: Muscarinic cholinergic receptors activate both inhibitory and stimulatory growth mechanisms in NIH3T3 cells. J Biol Chem 1999, 274:21701-21706.

75. Burdon D, Patel R, Challiss RA, Blank JL: Growth inhibition by the muscarinic $M(3)$ acetylcholine receptor: evidence for p2I(Cip I/WafI) involvement in G(I) arrest. Biochem J 2002, 367:549-559.

76. Brown JH, Sah V, Moskowitz S, Ramirez T, Collins L, Post G, Goldstein D: Pathways and roadblocks in muscarinic receptormediated growth regulation. Life Sci 1997, 60:1077-1084.

77. Shafer SH, Williams CL: Elevated Racl activity changes the $\mathbf{M} 3$ muscarinic acetylcholine receptor-mediated inhibition of proliferation to induction of cell death. Mol Pharmacol 2004, 65:1080-1091.

78. Lindenboim L, Pinkas-Kramarski R, Sokolovsky M, Stein R: Activation of muscarinic receptors inhibits apoptosis in PCI2MI cells. J Neurochem 1995, 64:2491-2499.

79. Leloup C, Michaelson DM, Fisher A, Hartmann T, Beyreuther K, Stein R: MI muscarinic receptors block caspase activation by phosphoinositide 3-kinase- and MAPK/ERK-independent pathways. Cell Death Differ 2000, 7:825-833.

80. De Sarno P, Shestopal SA, King TD, Zmijewska A, Song L, Jope RS: Muscarinic receptor activation protects cells from apoptotic effects of DNA damage, oxidative stress, and mitochondrial inhibition. J Biol Chem 2003, 278: I I086-I I093.
8I. Serobyan N, Orlovskaya I, Kozlov V, Khaldoyanidi SK: Exposure to nicotine during gestation interferes with the colonization of fetal bone marrow by hematopoietic stem/progenitor cells. Stem Cells Dev 2005, |4:8I-9I.

82. Budd DC, Spragg EJ, Ridd K, Tobin AB: Signalling of the M3-muscarinic receptor to the anti-apoptotic pathway. Biochem J 2004, 38I:43-49.

83. Budd DC, McDonald J, Emsley N, Cain K, Tobin AB: The C-terminal tail of the M3-muscarinic receptor possesses anti-apoptotic properties. J Biol Chem 2003, 278:|9565-19573.

84. Tipton DA, Dabbous MK: Effects of nicotine on proliferation and extracellular matrix production of human gingival fibroblasts in vitro. J Periodontol 1995, 66:1056-1064.

85. Peng X, Gerzanich V, Anand R, Wang F, Lindstrom J: Chronic nicotine treatment up-regulates alpha3 and alpha7 acetylcholine receptor subtypes expressed by the human neuroblastoma cell line SH-SY 5Y. Mol Pharmacol 1997, 5 I:776-784.

86. Wang F, Nelson ME, Kuryatov A, Olale F, Cooper J, Keyser K, Lindstrom J: Chronic nicotine treatment up-regulates human alpha3 beta2 but not alpha3 beta 4 acetylcholine receptors stably transfected in human embryonic kidney cells. J Biol Chem 1998, 273:28721-28732.

87. Giannopoulou C, Roehrich N, Mombelli A: Effect of nicotinetreated epithelial cells on the proliferation and collagen production of gingival fibroblasts. J Clin Periodontol 2001, 28:769-775.

88. Varker KA, Williams CL: Involvement of the muscarinic acetylcholine receptor in inhibition of cell migration. Biochem Pharmacol 2002, 63:597-605.

89. Chernyavsky Al, Arredondo J, Wess J, Karlsson E, Grando SA: Novel signaling pathways mediating reciprocal control of keratinocyte migration and wound epithelialization through M3 and M4 muscarinic receptors. J Cell Biol 2004, I 66:26I-272.

90. Yoon SY, Kim HW, Roh DH, Kwon YB, Han HJ, Beitz AJ, Lee JH: Intrathecal clonidine suppresses zymosan-induced peripheral leukocyte migration in a mouse air pouch model via activation of spinal muscarinic type 2 receptors and sympathoadrenal medullary activity. Neuropharmacology 2006, 51:829-837

91. Oppitz M, Mack A, Drews U: Ca2+-mobilization and cell contraction after muscarinic cholinergic stimulation of the chick embryo lens. Invest Ophthalmol Vis Sci 2003, 44:48I3-48I9.

92. Drews U, Mengis W: Contraction wave in the chick blastoderm induced by muscarinic stimulation. Anat Embryol (Berl) 1990 , I 82:447-454.

93. Sailer M, Oppitz M, Drews U: Induction of cellular contractions in the human melanoma cell line SK-mel 28 after muscarinic cholinergic stimulation. Anat Embryol (Berl) 2000, 20 I:27-37.

94. Koh JY, Palmer E, Cotman CW: Activation of the metabotropic glutamate receptor attenuates $\mathbf{N}$-methyl-D-aspartate neurotoxicity in cortical cultures. Proc Natl Acad Sci USA 1991, 88:9431-9435.

95. Yan GM, Lin SZ, Irwin RP, Paul SM: Activation of muscarinic cholinergic receptors blocks apoptosis of cultured cerebellar granule neurons. Mol Pharmacol 1995, 47:248-257.

96. Marte BM, Downward J: PKB/Akt: connecting phosphoinositide 3-kinase to cell survival and beyond. Trends Biochem Sci 1997, 22:355-358

97. Dudek H, Datta SR, Franke TF, Birnbaum MJ, Yao R, Cooper GM, Segal RA, Kaplan DR, Greenberg ME: Regulation of neuronal survival by the serine-threonine protein kinase Akt. Science 1997, 275:66।-665.

98. Kulik G, Klippel A, Weber MJ: Antiapoptotic signalling by the insulin-like growth factor I receptor, phosphatidylinositol 3kinase, and Akt. Mol Cell Biol 1997, I 7:1595-1606.

99. Murga C, Laguinge L, Wetzker R, Cuadrado A, Gutkind JS: Activation of Akt/protein kinase B by $\mathrm{G}$ protein-coupled receptors. J Biol Chem 1998, 273:19080-19085.

100. Desdouits-Magnen J, Desdouits F, Takeda S, Syu LJ, Saltiel AR, Buxbaum JD, Czernik AJ, Nairn AC, Greengard P: Regulation of secretion of Alzheimer amyloid precursor protein by the mitogen-activated protein kinase cascade. J Neurochem 1998, 70:524-530.

I0I. Ueda H, Morishita R, Narumiya S, Kato K, Asano T: Galphaq/ I I signaling induces apoptosis through two pathways involving reduction of Akt phosphorylation and activation of RhoA in HeLa cells. Exp Cell Res 2004, 298:207-2I7. 
102. Novakova J, Mikasova L, Machova E, Lisa V, Dolezal V: Chronic treatment with amyloid beta(I-42) inhibits non-cholinergic high-affinity choline transport in NGI08-I5 cells through protein kinase C signaling. Brain Res 2005, I 062: I O I-I I0.

103. Kodaira M, Kajimura M, Takeuchi K, Lin S, Hanai H, Kaneko E: Functional muscarinic $m 3$ receptor expressed in gastric cancer cells stimulates tyrosine phosphorylation and MAP kinase. J Gastroenterol 1999, 34:163-171.

104. Ukegawa JI, Takeuchi Y, Kusayanagi S, Mitamura K: Growth-promoting effect of muscarinic acetylcholine receptors in colon cancer cells. J Cancer Res Clin Oncol 2003, I 29:272-278.

105. Jimenez E, Montiel M: Activation of MAP kinase by muscarinic cholinergic receptors induces cell proliferation and protein synthesis in human breast cancer cells. J Cell Physiol 2005, 204:678-686.

106. Song P, Sekhon HS, Jia Y, Keller JA, Blusztajn JK, Mark GP, Spindel ER: Acetylcholine is synthesized by and acts as an autocrine growth factor for small cell lung carcinoma. Cancer Res 2003, 63:214-221

107. Xia Z, Dickens M, Raingeaud J, Davis RJ, Greenberg ME: Opposing effects of ERK and JNK-p38 MAP kinases on apoptosis. Science 1995, 270:|326-|33|.

108. Anderson CN, Tolkovsky AM: A role for MAPK/ERK in sympathetic neuron survival: protection against a p53-dependent, JNK-independent induction of apoptosis by cytosine arabinoside. J Neurosci 1999, 19:664-673.

109. Yao R, Cooper GM: Requirement for phosphatidylinositol-3 kinase in the prevention of apoptosis by nerve growth factor. Science 1995, 267:2003-2006.

I I0. Cardone MH, Roy N, Stennicke HR, Salvesen GS, Franke TF, Stanbridge E, Frisch S, Reed JC: Regulation of cell death protease caspase-9 by phosphorylation. Science 1998, 282:1318-132I.

III. Page C, Lin HJ, Jin Y, Castle VP, Nunez G, Huang M, Lin J: Overexpression of Akt/AKT can modulate chemotherapy-induced apoptosis. Anticancer Res 2000, 20:407-4I6.

I 12. Henshall DC, Araki T, Schindler CK, Lan JQ, Tiekoter KL, Taki W, Simon RP: Activation of Bcl-2-associated death protein and counter-response of Akt within cell populations during seizure-induced neuronal death. J Neurosci 2002, 22:8458-8465.

I 13. del Peso L, Gonzalez-Garcia M, Page C, Herrera R, Nunez G: Interleukin-3-induced phosphorylation of BAD through the protein kinase Akt. Science 1997, 278:687-689.

I 14. Kennedy SG, Wagner AJ, Conzen SD, Jordan J, Bellacosa A, Tsichlis PN, Hay N: The PI 3-kinase/Akt signaling pathway delivers an anti-apoptotic signal. Genes Dev 1997, I I:701-7I3.

I 15. Cui QL, Fogle E, Almazan G: Muscarinic acetylcholine receptors mediate oligodendrocyte progenitor survival through Srclike tyrosine kinases and PI3K/Akt pathways. Neurochem Int 2006, 48:383-393.

1 16. Datta SR, Brunet A, Greenberg ME: Cellular survival: a play in three Akts. Genes Dev 1999, I3:2905-2927.

I I7. Janssens V, Goris J: Protein phosphatase 2A: a highly regulated family of serine/threonine phosphatases implicated in cell growth and signalling. Biochem J 200I, 353:4I7-439.

I I8. Testa JR, Bellacosa A: AKT plays a central role in tumorigenesis. Proc Natl Acad Sci USA 2001, 98: 10983-10985.

I 19. Song G, Ouyang G, Bao S: The activation of Akt/PKB signaling pathway and cell survival. J Cell Mol Med 2005, 9:59-7I.

120. Yan CY, Greene LA: Prevention of PCI 2 cell death by $\mathbf{N}$-acetylcysteine requires activation of the Ras pathway. I Neurosci 1998, I 8:4042-4049.

12I. Hartfield PJ, Bilney AJ, Murray AW: Neurotrophic factors prevent ceramide-induced apoptosis downstream of c-Jun $\mathbf{N}$-terminal kinase activation in PCI2 cells. I Neurochem 1998, 71:161-169.

122. Pettigrew DB, Li YQ, Kuntz Ct, Crutcher KA: Global expression of NGF promotes sympathetic axonal growth in CNS white matter but does not alter its parallel orientation. Exp Neurol 2007, 203:95-109.

123. Ulrich E, Duwel A, Kauffmann-Zeh A, Gilbert C, Lyon D, Rudkin B, Evan G, Martin-Zanca D: Specific TrkA survival signals interfere with different apoptotic pathways. Oncogene 1998, 16:825-832.

124. Scheid MP, Duronio V: Dissociation of cytokine-induced phosphorylation of Bad and activation of PKB/akt: involvement of MEK upstream of Bad phosphorylation. Proc Natl Acad Sci USA 1998, 95:7439-7444.
125. Crowder RJ, Freeman RS: Phosphatidylinositol 3-kinase and Akt protein kinase are necessary and sufficient for the survival of nerve growth factor-dependent sympathetic neurons. J Neurosci 1998, I 8:2933-2943.

126. Bui NT, Konig HG, Culmsee C, Bauerbach E, Poppe M, Krieglstein J, Prehn $\mathrm{JH}$ : $\mathbf{p 7 5}$ neurotrophin receptor is required for constitutive and NGF-induced survival signalling in PCI 2 cells and rat hippocampal neurones. J Neurochem 2002, 8 I:594-605.

127. Zheng WH, Kar S, Quirion R: FKHRLI and its homologs are new targets of nerve growth factor Trk receptor signaling. J Neurochem 2002, 80:1049-106I.

128. Rakhit S, Pyne S, Pyne NJ: Nerve growth factor stimulation of p42/p44 mitogen-activated protein kinase in PCI 2 cells: role of $\mathbf{G}(\mathbf{i} / \mathrm{o}), \mathbf{G}$ protein-coupled receptor kinase 2 , beta-arrestin I, and endocytic processing. Mol Pharmacol 200I, 60:63-70.

129. Lou X, Yano H, Lee F, Chao MV, Farquhar MG: GIPC and GAIP form a complex with TrkA: a putative link between $\mathbf{G}$ protein and receptor tyrosine kinase pathways. Mol Biol Cell 200 I, I 2:615-627.

130. Kanoh Y, Ishizuka T, Morita H, Ishizawa M, Miura A, Kajita K, Kimura M, Suzuki T, Sakuma H, Yasuda K: Effect of pertussis toxin on insulin-induced signal transduction in rat adipocytes and soleus muscles. Cell Signal 2000, I 2:223-232.

131. Balteskard L, Unneberg K, Mjaaland M, Jenssen TG, Revhaug A: Growth hormone and insulinlike growth factor I promote intestinal uptake and hepatic release of glutamine in sepsis. Ann Surg 1998, 228: I31-139.

132. Kim S, Garcia A, Jackson SP, Kunapuli SP: Insulin-like growth factor-I regulates platelet activation through PI3-Kalpha isoform. Blood 2007, I 1 0:4206-42 I3.

133. Moughal NA, Waters C, Sambi B, Pyne S, Pyne NJ: Nerve growth factor signaling involves interaction between the Trk $A$ receptor and lysophosphatidate receptor I systems: nuclear translocation of the lysophosphatidate receptor I and Trk A receptors in pheochromocytoma 12 cells. Cell Signal 2004, 1 6:127-136.

134. Piiper A, Zeuzem S: Receptor tyrosine kinases are signaling intermediates of $\mathbf{G}$ protein-coupled receptors. Curr Pharm Des 2004, 10:3539-3545.

135. Natarajan K, Berk BC: Crosstalk coregulation mechanisms of G protein-coupled receptors and receptor tyrosine kinases. Methods Mol Biol 2006, 332:5I-77.

136. Zhao Y, He D, Stern R, Usatyuk PV, Spannhake EW, Salgia R, Natarajan $\mathrm{V}$ : Lysophosphatidic acid modulates $\mathrm{c}$-Met redistribution and hepatocyte growth factor/c-Met signaling in human bronchial epithelial cells through PKC delta and E-cadherin. Cell Signal 2007, 19:2329-2338.

137. Xie P, Browning DD, Hay N, Mackman N, Ye RD: Activation of NFkappa B by bradykinin through a Galpha(q)- and Gbeta gamma-dependent pathway that involves phosphoinositide 3-kinase and Akt. J Biol Chem 2000, 275:24907-249l4.

138. Clerk A, Aggeli IK, Stathopoulou K, Sugden PH: Peptide growth factors signal differentially through protein kinase $C$ to extracellular signal-regulated kinases in neonatal cardiomyocytes. Cell Signal 2006, I 8:225-235.

139. Chong ZZ, Lin SH, Li F, Maiese K: The sirtuin inhibitor nicotinamide enhances neuronal cell survival during acute anoxic injury through AKT, BAD, PARP, and mitochondrial associated "anti-apoptotic" pathways. Curr Neurovasc Res 2005, 2:27I-285.

140. Chong ZZ, Li F, Maiese K: Erythropoietin requires NF-kappaB and its nuclear translocation to prevent early and late apoptotic neuronal injury during beta-amyloid toxicity. Curr Neurovasc $\operatorname{Res} 2005$, 2:387-399.

14I. Laychock SG, Sessanna SM, Lin MH, Mastrandrea LD: Sphingosine I-phosphate affects cytokine-induced apoptosis in rat pancreatic islet beta-cells. Endocrinology 2006, I 47:4705-47I2.

142. Meyer zu Heringdorf D, Lass H, Kuchar I, Alemany R, Guo Y, Schmidt $\mathrm{M}$, Jakobs $\mathrm{KH}$ : Role of sphingosine kinase in $\mathbf{C a ( 2 + )}$ signalling by epidermal growth factor receptor. FEBS Lett 1999 , 46 I:2 I 7-222

143. Xiang J, Chao DT, Korsmeyer S]: BAX-induced cell death may not require interleukin I beta-converting enzyme-like proteases. Proc Natl Acad Sci USA 1996, 93:14559-|4563.

144. Wang NS, Unkila MT, Reineks EZ, Distelhorst CW: Transient expression of wild-type or mitochondrially targeted $\mathrm{Bcl}-2$ 
induces apoptosis, whereas transient expression of endoplasmic reticulum-targeted $\mathrm{Bcl}-2$ is protective against Baxinduced cell death. J Biol Chem 200I, 276:44II 7-44I28.

145. Li A, Harris DA: Mammalian prion protein suppresses Baxinduced cell death in yeast. J Biol Chem 2005, 280: 17430-17434.

146. Facchinetti $F$, Furegato $S$, Terrazzino $S$, Leon $A: \mathbf{H ( 2 ) O ( 2 )}$ induces upregulation of Fas and Fas ligand expression in NGF-differentiated PCI 2 cells: modulation by cAMP. J Neurosci Res 2002, 69:178-188.

147. Ulloth JE, Casiano CA, De Leon M: Palmitic and stearic fatty acids induce caspase-dependent and -independent cell death in nerve growth factor differentiated PCI 2 cells. J Neurochem 2003, 84:655-668.

148. Liu XB, Masago R, Kong L, Zhang BX, Masago S, Vela-Roch N, Katz MS, Yeh CK, Zhang GH, Talal N, Dang H: G-protein signaling abnormalities mediated by CD95 in salivary epithelial cells. Cell Death Differ 2000, 7: I II9-II26.

149. Pugazhenthi S, Boras T, O'Connor D, Meintzer MK, Heidenreich KA Reusch JE: Insulin-like growth factor I-mediated activation of the transcription factor CAMP response element-binding protein in PCI 2 cells. J Biol Chem 1999, 274:2829-2837.

150. Zheng WH, Kar S, Quirion R: Insulin-like growth factor-Iinduced phosphorylation of the forkhead family transcription factor FKHRLI is mediated by Akt kinase in PCI 2 cells. J Biol Chem 2000, 275:39152-39158.

I5I. Kozma R, Sarner S, Ahmed S, Lim L: Rho family GTPases and neuronal growth cone remodelling: relationship between increased complexity induced by $\mathrm{Cdc} 42 \mathrm{Hs}$, Racl, and acetylcholine and collapse induced by RhoA and lysophosphatidic acid. Mol Cell Biol 1997, 17:1201-1211.

152. Linseman DA, Heidenreich KA, Fisher SK: Stimulation of M3 muscarinic receptors induces phosphorylation of the $\mathrm{Cdc42}$ effector activated Cdc42Hs-associated kinase-I via a Fyn tyrosine kinase signaling pathway. I Biol Chem 200I, 276:5622-5628.

153. Kimura K, Ito M, Amano M, Chihara K, Fukata Y, Nakafuku M, Yamamori B, Feng J, Nakano T, Okawa K, et al.: Regulation of myosin phosphatase by Rho and Rho-associated kinase (Rhokinase). Science 1996, 273:245-248.

154. Wang Y, Yoshioka K, Azam MA, Takuwa N, Sakurada S, Kayaba Y, Sugimoto N, Inoki I, Kimura T, Kuwaki T, Takuwa Y: Class II phosphoinositide 3-kinase alpha-isoform regulates Rho, myosin phosphatase and contraction in vascular smooth muscle. Biochem J 2006, 394:58I-592.

155. Fromm C, Coso OA, Montaner S, Xu N, Gutkind IS: The small GTP-binding protein Rho links $G$ protein-coupled receptors and Galpha 2 to the serum response element and to cellular transformation. Proc Natl Acad Sci USA 1997, 94: 10098-10103.

156. Shaw S, Bencherif M, Marrero MB: Janus kinase 2, an early target of alpha 7 nicotinic acetylcholine receptor-mediated neuroprotection against Abeta-(I-42) amyloid. I Biol Chem 2002, 277:44920-44924.

157. Brunet A, Bonni A, Zigmond MJ, Lin MZ, Juo P, Hu LS, Anderson MJ, Arden KC, Blenis J, Greenberg ME: Akt promotes cell survival by phosphorylating and inhibiting a Forkhead transcription factor. Cell 1999, 96:857-868.

158. Cahill CM, Tzivion G, Nasrin N, Ogg S, Dore J, Ruvkun G, AlexanderBridges M: Phosphatidylinositol 3-kinase signaling inhibits DAF- 16 DNA binding and function via |4-3-3-dependent and 14-3-3-independent pathways. J Biol Chem 200I, 276: $13402-13410$

159. Rena G, Prescott AR, Guo S, Cohen P, Unterman TG: Roles of the forkhead in rhabdomyosarcoma (FKHR) phosphorylation sites in regulating | 4-3-3 binding, transactivation and nuclear targetting. Biochem J 200I, 354:605-6I2.

160. Zeidler R, Albermann K, Lang S: Nicotine and apoptosis. Apoptosis 2007, 1 2:1927-1943.

16I. Mai H, May WS, Gao F, Jin Z, Deng X: A functional role for nicotine in Bcl2 phosphorylation and suppression of apoptosis. J Biol Chem 2003, 278: | 886-I89|.

162. West KA, Brognard J, Clark AS, Linnoila IR, Yang X, Swain SM, Harris C, Belinsky S, Dennis PA: Rapid Akt activation by nicotine and a tobacco carcinogen modulates the phenotype of normal human airway epithelial cells. J Clin Invest 2003, I I I:8I-90.
163. Jin Z, Gao F, Flagg T, Deng X: Nicotine induces multi-site phosphorylation of Bad in association with suppression of apoptosis. J Biol Chem 2004, 279:23837-23844.

164. Scheid MP, Schubert KM, Duronio V: Regulation of bad phosphorylation and association with $\mathrm{Bcl}-\mathrm{x}(\mathrm{L})$ by the MAPK/Erk kinase. J Biol Chem 1999, 274:3 I I08-3III3.

165. Datta SR, Dudek H, Tao X, Masters S, Fu H, Gotoh Y, Greenberg ME: Akt phosphorylation of BAD couples survival signals to the cell-intrinsic death machinery. Cell 1997, 9 I:23I-24I.

166. Zhou XM, Liu Y, Payne G, Lutz RJ, Chittenden T: Growth factors inactivate the cell death promoter BAD by phosphorylation of its BH3 domain on Serl55. I Biol Chem 2000, 275:25046-2505I.

167. Fang X, Yu S, Eder A, Mao M, Bast RC Jr, Boyd D, Mills GB: Regulation of BAD phosphorylation at serine $1 / 2$ by the Rasmitogen-activated protein kinase pathway. Oncogene 1999 , 18:6635-6640.

168. Schuller HM: Is cancer triggered by altered signalling of nicotinic acetylcholine receptors? Nat Rev Cancer 2009, 9:1 95-205.

169. Xin M, Deng X: Nicotine inactivation of the proapoptotic function of Bax through phosphorylation. J Biol Chem 2005, 280: 1078I-10789.

170. Xin M, Gao F, May WS, Flagg T, Deng X: Protein kinase Czeta abrogates the proapoptotic function of Bax through phosphorylation. J Biol Chem 2007, 282:2 I 268-2 I 277.

17I. Dasgupta P, Kinkade R, Joshi B, Decook C, Haura E, Chellappan S: Nicotine inhibits apoptosis induced by chemotherapeutic drugs by up-regulating XIAP and survivin. Proc Natl Acad Sci USA 2006, 103:6332-6337.

172. Kihara T, Shimohama S, Sawada H, Honda K, Nakamizo T, Shibasaki $H$, Kume T, Akaike A: alpha 7 nicotinic receptor transduces signals to phosphatidylinositol 3-kinase to block A beta-amyloid-induced neurotoxicity. J Biol Chem 200I, 276: I354I-I 3546.

173. Berger F, Gage FH, Vijayaraghavan S: Nicotinic receptor-induced apoptotic cell death of hippocampal progenitor cells. J Neurosci |998, | 8:687|-688|.

174. Guan ZZ, Yu WF, Nordberg A: Dual effects of nicotine on oxidative stress and neuroprotection in PCI 2 cells. Neurochem Int 2003, 43:243-249.

175. Hejmadi MV, Dajas-Bailador F, Barns SM, Jones B, Wonnacott S: Neuroprotection by nicotine against hypoxia-induced apoptosis in cortical cultures involves activation of multiple nicotinic acetylcholine receptor subtypes. Mol Cell Neurosci 2003 , 24:779-786.

176. Jonnala RR, Graham JH 3rd, Terry AV Jr, Beach JW, Young JA, Buccafusco JJ: Relative levels of cytoprotection produced by analogs of choline and the role of alpha7-nicotinic acetylcholine receptors. Synapse 2003, 47:262-269.

177. Okuda S, Saito H, Katsuki H: Arachidonic acid: toxic and trophic effects on cultured hippocampal neurons. Neuroscience 1994 , 63:691-699.

178. Serova L, Sabban EL: Involvement of alpha 7 nicotinic acetylcholine receptors in gene expression of dopamine biosynthetic enzymes in rat brain. J Pharmacol Exp Ther 2002, 303:896-903

179. Belluardo N, Mudo G, Blum M, Itoh N, Agnati L, Fuxe K: Nicotineinduced FGF-2 mRNA in rat brain is preserved during aging. Neurobiol Aging 2004, 25: 1333-1342.

180. Hsu YN, Edwards SC, Wecker L: Nicotine enhances the cyclic AMP-dependent protein kinase-mediated phosphorylation of alpha4 subunits of neuronal nicotinic receptors. I Neurochem 1997, 69:2427-2431.

18I. Garrido R, Mattson MP, Hennig B, Toborek M: Nicotine protects against arachidonic-acid-induced caspase activation, cytochrome $c$ release and apoptosis of cultured spinal cord neurons. J Neurochem 200I, 76:1395-I 403.

182. Nakayama H, Shioda S, Okuda H, Nakashima T, Nakai Y: Immunocytochemical localization of nicotinic acetylcholine receptor in rat cerebral cortex. Brain Res Mol Brain Res 1995, 32:321-328.

183. Berg DK, Conroy WG: Nicotinic alpha 7 receptors: synaptic options and downstream signaling in neurons. I Neurobiol 2002, 53:512-523.

184. Trombino S, Cesario A, Margaritora S, Granone P, Motta G, Falugi C, Russo P: Alpha7-nicotinic acetylcholine receptors affect growth regulation of human mesothelioma cells: role of 
mitogen-activated protein kinase pathway. Cancer Res 2004, 64:135-145

185. Schuller HM, Tithof PK, Williams M, Plummer H 3rd: The tobaccospecific carcinogen 4-(methylnitrosamino)-I-(3-pyridyl)-Ibutanone is a beta-adrenergic agonist and stimulates DNA synthesis in lung adenocarcinoma via beta-adrenergic receptor-mediated release of arachidonic acid. Cancer Res 1999 , 59:4510-45।5.

186. Gimonet D, Grailhe R, Coninx P, Antonicelli F, Haye B, LiautaudRoger F: Functional role of nicotinic acetylcholine receptors in apoptosis in HL-60 cell line. Eur J Pharmacol 2003, 482:25-29.

187. Heusch WL, Maneckjee R: Signalling pathways involved in nicotine regulation of apoptosis of human lung cancer cells. Carcinogenesis 1998, 19:55I-556.

188. Finkbeiner S: CREB couples neurotrophin signals to survival messages. Neuron 2000, 25:II-14.

189. Mazzucchelli C, Brambilla R: Ras-related and MAPK signalling in neuronal plasticity and memory formation. Cell Mol Life Sci 2000, 57:604-6II.

190. Zhu Y, Culmsee C, Klumpp S, Krieglstein J: Neuroprotection by transforming growth factor-betal involves activation of nuclear factor-kappaB through phosphatidylinositol-3-OH kinase/Akt and mitogen-activated protein kinase-extracellular-signal regulated kinase I,2 signaling pathways. Neuroscience 2004, I 23:897-906.

191. Mattson MP, Culmsee C, Yu Z, Camandola S: Roles of nuclear factor kappaB in neuronal survival and plasticity. I Neurochem 2000, 74:443-456.

192. Mayr B, Montminy M: Transcriptional regulation by the phosphorylation-dependent factor CREB. Nat Rev Mol Cell Biol 200I, 2:599-609.

193. Zha XM, Bishop JF, Hansen MR, Victoria L, Abbas PJ, Mouradian MM, Green SH: BDNF synthesis in spiral ganglion neurons is constitutive and CREB-dependent. Hear Res 200 I, 156:53-68.

194. Wasylyk B, Hagman J, Gutierrez-Hartmann A: Ets transcription factors: nuclear effectors of the Ras-MAP-kinase signaling pathway. Trends Biochem Sci 1998, 23:213-216.

195. Shibata F, Baird A, Florkiewicz RZ: Functional characterization of the human basic fibroblast growth factor gene promoter. Growth Factors 1991, 4:277-287.

196. Schweppe RE, Frazer-Abel AA, Gutierrez-Hartmann A, Bradford AP: Functional components of fibroblast growth factor (FGF) signal transduction in pituitary cells. I Biol Chem 1997, 272:30852-30859.

197. Zhou C, Wen ZX, Shi DM, Xie ZP: Muscarinic acetylcholine receptors involved in the regulation of neural stem cell proliferation and differentiation in vitro. Cell Biol lnt 2004, 28:63-67.

198. Jang YY, Sharkis SJ: Stem cell plasticity: a rare cell, not a rare event. Stem Cell Rev 2005, I:45-5I.

199. Chang L, Karin M: Mammalian MAP kinase signalling cascades. Nature 200I, 410:37-40.

200. Resende RR, Faria M, Ulrich $H$ : The contribution of nitric oxide and carbon monoxide to neuronal function and development. Central Nervous System Agents in Medicinal Chemistry 2007, 7:85-96.

201. Felder CC: Muscarinic acetylcholine receptors: signal transduction through multiple effectors. Faseb J 1995, 9:619-625.

202. Iwasaki H, Shichiri M, Marumo F, Hirata Y: Adrenomedullin stimulates proline-rich tyrosine kinase 2 in vascular smooth muscle cells. Endocrinology 200I, | 42:564-572.

203. Della Rocca G], Mukhin YV, Garnovskaya MN, Daaka Y, Clark G], Luttrell LM, Lefkowitz RJ, Raymond JR: Serotonin 5-HTIA receptormediated Erk activation requires calcium/calmodulindependent receptor endocytosis. I Biol Chem 1999 274:4749-4753.

204. Kolch W, Heidecker G, Kochs G, Hummel R, Vahidi H, Mischak H, Finkenzeller G, Marme D, Rapp UR: Protein kinase $\mathbf{C}$ alpha activates RAF-I by direct phosphorylation. Nature 1993, 364:249-252.

205. Shah BH, Catt KJ: Calcium-independent activation of extracellularly regulated kinases $I$ and 2 by angiotensin II in hepatic C9 cells: roles of protein kinase Cdelta, Src/proline-rich tyrosine kinase 2, and epidermal growth receptor trans-activation. Mol Pharmacol 2002, 61:343-351.

206. Liebmann C, Bohmer FD: Signal transduction pathways of G protein-coupled receptors and their cross-talk with receptor tyrosine kinases: lessons from bradykinin signaling. Curr Med Chem 2000, 7:91।-943

207. Pearson G, Robinson F, Beers Gibson T, Xu BE, Karandikar M, Berman K, Cobb MH: Mitogen-activated protein (MAP) kinase pathways: regulation and physiological functions. Endocr Rev 200I, 22:153-I83.

208. Wilkinson MG, Millar JB: Control of the eukaryotic cell cycle by MAP kinase signaling pathways. Faseb J 2000, 14:2/47-2157.

209. Li BS, Ma W, Zhang L, Barker JL, Stenger DA, Pant HC: Activation of phosphatidylinositol-3 kinase (PI-3K) and extracellular regulated kinases $(E r k \mathrm{I} / 2)$ is involved in muscarinic receptor-mediated DNA synthesis in neural progenitor cells. J Neurosci 200I, 2 I:I569-I579.

210. Allen LF, Lefkowitz RJ, Caron MG, Cotecchia S: G-protein-coupled receptor genes as protooncogenes: constitutively activating mutation of the alpha IB-adrenergic receptor enhances mitogenesis and tumorigenicity. Proc Natl Acad Sci USA I991, 88: I I354- I I358.

21I. Gutkind JS, Novotny EA, Brann MR, Robbins KC: Muscarinic acetylcholine receptor subtypes as agonist-dependent oncogenes. Proc Natl Acad Sci USA 199I, 88:4703-4707.

212. Couty JP, Gershengorn MC: Insights into the viral G proteincoupled receptor encoded by human herpesvirus type 8 (HHV-8). Biol Cell 2004, 96:349-354.

213. Vischer HF, Leurs R, Smit MJ: HCMV-encoded G-protein-coupled receptors as constitutively active modulators of cellular signaling networks. Trends Pharmacol Sci 2006, 27:56-63.

214. Ballif BA, Blenis J: Molecular mechanisms mediating mammalian mitogen-activated protein kinase (MAPK) kinase (MEK)MAPK cell survival signals. Cell Growth Differ 200I, I 2:397-408.

215. Mercer SE, Friedman E: Mirk/DyrkIB: a multifunctional dualspecificity kinase involved in growth arrest, differentiation, and cell survival. Cell Biochem Biophys 2006, 45:303-3I5.

216. Dhanasekaran DN, Kashef K, Lee CM, Xu H, Reddy EP: Scaffold proteins of MAP-kinase modules. Oncogene 2007, 26:3185-3202.

217. Pronk G], Bos JL: The role of p2 I ras in receptor tyrosine kinase signalling. Biochim Biophys Acta 1994, I I 98: I3I-147.

218. van Corven EJ, Hordijk PL, Medema RH, Bos JL, Moolenaar WH: Pertussis toxin-sensitive activation of $\mathbf{p} 2$ I ras by $\mathbf{G}$ protein-coupled receptor agonists in fibroblasts. Proc Natl Acad Sci USA 1993, 90:|257-|26|.

219. Koch WJ, Hawes BE, Allen LF, Lefkowitz RJ: Direct evidence that Gi-coupled receptor stimulation of mitogen-activated protein kinase is mediated by $\mathbf{G}$ beta gamma activation of p2 I ras. Proc Natl Acad Sci USA 1994, 9 I: 12706- 227 I0.

220. Daub H, Weiss FU, Wallasch C, Ullrich A: Role of transactivation of the EGF receptor in signalling by G-protein-coupled receptors. Nature 1996, 379:557-560.

22I. Eguchi S, Numaguchi K, Iwasaki H, Matsumoto T, Yamakawa T, Utsunomiya $\mathrm{H}$, Motley ED, Kawakatsu H, Owada KM, Hirata Y, et al:: Calcium-dependent epidermal growth factor receptor transactivation mediates the angiotensin II-induced mitogen-activated protein kinase activation in vascular smooth muscle cells. J Biol Chem 1998, 273:8890-8896.

222. Hawes BE, van Biesen T, Koch WJ, Luttrell LM, Lefkowitz RJ: Distinct pathways of $\mathrm{Gi}$ - and $\mathrm{Gq}$-mediated mitogen-activated protein kinase activation. J Biol Chem 1995, 270:17|48-17/53.

223. Blaukat A, Barac A, Cross MJ, Offermanns S, Dikic I: G protein-coupled receptor-mediated mitogen-activated protein kinase activation through cooperation of Galpha(q) and Galpha(i) signals. Mol Cell Biol 2000, 20:6837-6848.

224. Winitz S, Russell M, Qian NX, Gardner A, Dwyer L, Johnson GL: Involvement of Ras and Raf in the Gi-coupled acetylcholine muscarinic $\mathrm{m} 2$ receptor activation of mitogen-activated protein (MAP) kinase kinase and MAP kinase. J Biol Chem 1993 , 268:19196-19199.

225. Russell M, Winitz S, Johnson GL: Acetylcholine muscarinic $\mathbf{m}$ I receptor regulation of cyclic AMP synthesis controls growth factor stimulation of Raf activity. Mol Cell Biol 1994, 14:2343-235I.

226. Guizzetti M, Costa LG: Activation of phosphatidylinositol 3 kinase by muscarinic receptors in astrocytoma cells. Neuroreport 200I, 12:1639-1642.

227. Yeo A, Samways DS, Fowler CE, Gunn-Moore F, Henderson G Coincident signalling between the Gi/Go-coupled delta-opi- 
oid receptor and the Gq-coupled $\mathrm{m} 3$ muscarinic receptor at the level of intracellular free calcium in SH-SY5Y cells. J Neurochem 200I, 76:1688-1700.

228. Berkeley JL, Levey Al: Cell-specific extracellular signal-regulated kinase activation by multiple $\mathbf{G}$ protein-coupled receptor families in hippocampus. Mol Pharmacol 2003, 63:128-135.

229. Chan AS, Yeung WW, Wong YH: Integration of G protein signals by extracellular signal-regulated protein kinases in SKN-MC neuroepithelioma cells. J Neurochem 2005, 94: I457- I 470.

230. Slack BE: The $\mathbf{m} 3$ muscarinic acetylcholine receptor is coupled to mitogen-activated protein kinase via protein kinase $C$ and epidermal growth factor receptor kinase. Biochem 2000, 348(Pt 2):38I-387.

23I. Rosenblum K, Futter M, Jones M, Hulme EC, Bliss TV: ERKI/II regulation by the muscarinic acetylcholine receptors in neurons. J Neurosci 2000, 20:977-985.

232. Montiel M, Pavia J, Marsigliante S, Jimenez E: Activation of muscarinic acetylcholine receptors induces $\mathrm{Ca}(2+)$ mobilization in FRT cells. Cell Signal 200I, I 3:207-2I2.

233. Montiel M, Quesada J, Jimenez E: Activation of second messenger-dependent protein kinases induces muscarinic acetylcholine receptor desensitization in rat thyroid epithelial cells. Mol Cell Endocrinol 2004, 223:35-4I.

234. Fan WT, Koch CA, de Hoog CL, Fam NP, Moran MF: The exchange factor Ras-GRF2 activates Ras-dependent and Rac-dependent mitogen-activated protein kinase pathways. Curr Biol 1998, 8:935-938

235. Ebinu JO, Stang SL, Teixeira C, Bottorff DA, Hooton J, Blumberg PM, Barry M, Bleakley RC, Ostergaard HL, Stone JC: RasGRP links T. cell receptor signaling to Ras. Blood 2000, 95:3199-3203.

236. Sanjuan MA, Pradet-Balade B, Jones DR, Martinez AC, Stone JC, Garcia-Sanz JA, Merida I: T cell activation in vivo targets diacylglycerol kinase alpha to the membrane: a novel mechanism for Ras attenuation. J Immunol 2003, I 70:2877-2883.

237. Hamilton SE, Nathanson NM: The MI receptor is required for muscarinic activation of mitogen-activated protein (MAP) kinase in murine cerebral cortical neurons. J Biol Chem 200I, 276: $15850-15853$

238. Keely SJ, Calandrella SO, Barrett KE: Carbachol-stimulated transactivation of epidermal growth factor receptor and mitogenactivated protein kinase in $T(84)$ cells is mediated by intracellular ca(2+), PYK-2, and p60(src). I Biol Chem 2000, 275: $12619-12625$.

239. Derkinderen P, Siciliano J, Toutant M, Girault JA: Differential regulation of FAK+ and PYK2/Cakbeta, two related tyrosine kinases, in rat hippocampal slices: effects of LPA, carbachol, depolarization and hyperosmolarity. Eur J Neurosci 1998, I0:1667-I675

240. Li X, Lee JW, Graves LM, Earp HS: Angiotensin II stimulates ERK via two pathways in epithelial cells: protein kinase $C$ suppresses a G-protein coupled receptor-EGF receptor transactivation pathway. Embo J 1998, 17:2574-2583.

24I. Jope RS, Song L, Grimes CA, Zhang L: Oxidative stress oppositely modulates protein tyrosine phosphorylation stimulated by muscarinic $\mathbf{G}$ protein-coupled and epidermal growth factor receptors. J Neurosci Res 1999, 55:329-340.

242. Shah BH, Olivares-Reyes JA, Catt KJ: The protein kinase $\mathbf{C}$ inhibitor Go6976 [12-(2-cyanoethyl)-6,7,12,13-tetrahydro-13 methyl-5-oxo-5H-indolo(2,3-a)py rrolo(3,4-c)-carbazole] potentiates agonist-induced mitogen-activated protein kinase activation through tyrosine phosphorylation of the epidermal growth factor receptor. Mol Pharmacol 2005 67:184-194.

243. Crespo P, Xu N, Daniotti JL, Troppmair J, Rapp UR, Gutkind JS: Signaling through transforming $G$ protein-coupled receptors in NIH 3T3 cells involves c-Raf activation. I Biol Chem 1994, 269:21103-21109.

244. Hawkins BT, Egleton RD, Davis TP: Modulation of cerebral microvascular permeability by endothelial nicotinic acetylcholine receptors. Am / Physiol Heart Circ Physiol 2005, 289: $\mathrm{H} 212-219$.

245. Abbruscato TJ, Lopez SP, Roder K, Paulson JR: Regulation of blood-brain barrier $\mathrm{Na}, \mathrm{K}, 2 \mathrm{Cl}$-cotransporter through phosphorylation during in vitro stroke conditions and nicotine exposure. J Pharmacol Exp Ther 2004, 3 1 0:459-468.
246. Howard MJ, Gershon MD, Margiotta JF: Expression of nicotinic acetylcholine receptors and subunit mRNA transcripts in cultures of neural crest cells. Dev Biol 1995, I70:479-495

247. De Simone R, Ajmone-Cat MA, Carnevale D, Minghetti L: Activation of alpha7 nicotinic acetylcholine receptor by nicotine selectively up-regulates cyclooxygenase- 2 and prostaglandin E2 in rat microglial cultures. J Neuroinflammation 2005, 2:4.

248. Sharma G, Vijayaraghavan S: Nicotinic receptor signaling in nonexcitable cells. J Neurobiol 2002, 53:524-534.

249. Conklin BS, Zhao W, Zhong DS, Chen C: Nicotine and cotinine up-regulate vascular endothelial growth factor expression in endothelial cells. Am J Pathol 2002, 160:4|3-4|8.

250. $\mathrm{Xu} \mathrm{L}$, Deng $X$ : Protein kinase Ciota promotes nicotineinduced migration and invasion of cancer cells via phosphorylation of micro- and m-calpains. I Biol Chem 2006, 28I:4457-4466

25I. Shin VY, Wu WK, Chu KM, Wong HP, Lam EK, Tai EK, Koo MW, Cho $\mathrm{CH}$ : Nicotine induces cyclooxygenase-2 and vascular endothelial growth factor receptor-2 in association with tumor-associated invasion and angiogenesis in gastric cancer. Mol Cancer Res 2005, 3:607-6I5.

252. Chu M, Guo J, Chen CY: Long-term exposure to nicotine, via ras pathway, induces cyclin DI to stimulate GI cell cycle transition. J Biol Chem 2005, 280:6369-6379.

253. Dasgupta P, Rastogi S, Pillai S, Ordonez-Ercan D, Morris M, Haura E, Chellappan S: Nicotine induces cell proliferation by beta-arrestin-mediated activation of Src and Rb-Raf-I pathways. J Clin Invest 2006, I I 6:2208-22I7.

254. Leanza G, Muir J, Nilsson OG, Wiley RG, Dunnett SB, Bjorklund A Selective immunolesioning of the basal forebrain cholinergic system disrupts short-term memory in rats. Eur J Neurosci 1996, 8: I535-1544

255. Xie DP, Chen LB, Liu CY, Zhang CL, Liu KJ, Wang PS: Arecoline excites the colonic smooth muscle motility via M3 receptor in rabbits. Chin J Physiol 2004, 47:89-94.

256. Margiotta JF, Berg DK, Dionne VE: The properties and regulation of functional acetylcholine receptors on chick ciliary ganglion neurons. J Neurosci 1987, 7:36|2-3622.

257. Arias HR: Agonist self-inhibitory binding site of the nicotinic acetylcholine receptor. I Neurosci Res 1996, 44:97-105.

258. Sokolova E, Matteoni C, Nistri A: Desensitization of neuronal nicotinic receptors of human neuroblastoma SH-SY5Y cells during short or long exposure to nicotine. BrJ Pharmacol 2005, 146:1087-1095

259. Mulle C, Benoit P, Pinset C, Roa M, Changeux JP: Calcitonin generelated peptide enhances the rate of desensitization of the nicotinic acetylcholine receptor in cultured mouse muscle cells. Proc Natl Acad Sci USA 1988, 85:5728-5732.

260. Miles K, Greengard P, Huganir RL: Calcitonin gene-related peptide regulates phosphorylation of the nicotinic acetylcholine receptor in rat myotubes. Neuron 1989, 2:1517-1524.

26I. Giniatullin R, Di Angelantonio S, Marchetti C, Sokolova E, Khiroug L, Nistri A: Calcitonin gene-related peptide rapidly downregulates nicotinic receptor function and slowly raises intracellular Ca2+ in rat chromaffin cells in vitro. J Neurosci 1999, 19:2945-2953.

262. Di Angelantonio S, Costa V, Carloni P, Messori L, Nistri A: A novel class of peptides with facilitating action on neuronal nicotinic receptors of rat chromaffin cells in vitro: functional and molecular dynamics studies. Mol Pharmacol 2002, 61:43-54.

263. Leonard S, Gault J, Hopkins J, Logel J, Vianzon R, Short M, Drebing C, Berger R, Venn D, Sirota P, et al.: Association of promoter variants in the alpha7 nicotinic acetylcholine receptor subunit gene with an inhibitory deficit found in schizophrenia. Arch Gen Psychiatry 2002, 59:1085-1096.

264. D'Ascenzo M, Piacentini R, Casalbore P, Budoni M, Pallini R, Azzena GB, Grassi C: Role of L-type Ca2+ channels in neural stem/ progenitor cell differentiation. Eur J Neurosci 2006, 23:935-944.

265. Resende RR, da Costa JL, Kihara AH, Adhikari A, Lorencon E: Intracellular $\mathrm{Ca}(2+)$ Regulation During Neuronal Differentiation of Murine Embryonal Carcinoma and Mesenchymal Stem Cells. Stem Cells Dev 2008 in press.

266. Nagasawa K, Tarui T, Yoshida S, Sekiguchi F, Matsunami M, Ohi A, Fukami K, Ichida S, Nishikawa $H$, Kawabata A: Hydrogen sulfide evokes neurite outgrowth and expression of high-voltage- 
activated $\mathrm{Ca} 2+$ currents in NGI08-15 cells: involvement of T-type Ca2+ channels. J Neurochem 2009, 108:676-684.

267. Hirooka K, Bertolesi GE, Kelly ME, Denovan-Wright EM, Sun X, Hamid J, Zamponi GW, Juhasz AE, Haynes LW, Barnes S: T-Type calcium channel alphalG and alphalH subunits in human retinoblastoma cells and their loss after differentiation. J Neurophysiol 2002, 88: 196-205.

268. Bertolesi GE, Shi C, Elbaum L, Jollimore C, Rozenberg G, Barnes S, Kelly ME: The $\mathbf{C a}(2+)$ channel antagonists mibefradil and pimozide inhibit cell growth via different cytotoxic mechanisms. Mol Pharmacol 2002, 62:210-219.

269. Mason RP, Leeds PR, Jacob RF, Hough CJ, Zhang KG, Mason PE, Chuang DM: Inhibition of excessive neuronal apoptosis by the calcium antagonist amlodipine and antioxidants in cerebellar granule cells. J Neurochem 1999, 72: I448-I 456.

270. Yamagata K, Ichinose S, Tagami M: Amlodipine and carvedilol prevent cytotoxicity in cortical neurons isolated from stroke-prone spontaneously hypertensive rats. Hypertens Res 2004, 27:27I-282.

27I. Brinton RD, Wang JM: Preclinical analyses of the therapeutic potential of allopregnanolone to promote neurogenesis in vitro and in vivo in transgenic mouse model of Alzheimer's disease. Curr Alzheimer Res 2006, 3: I I- I7.

272. Liu JW, Tian SJ, de Barry J, Luu B: Panaxadiol glycosides that induce neuronal differentiation in neurosphere stem cells. J Nat Prod 2007, 70:1329-I334.

273. Yoshida J, Ishibashi T, Nishio M: Antiproliferative effect of Ca2+ channel blockers on human epidermoid carcinoma A43 I cells. Eur J Pharmacol 2003, 472:23-3I.

274. Arredondo J, Chernyavsky AI, Grando SA: SLURP-I and -2 in normal, immortalized and malignant oral keratinocytes. Life Sci 2007, 80:2243-2247.

Publish with Biomed Central and every scientist can read your work free of charge

"BioMed Central will be the most significant development for disseminating the results of biomedical research in our lifetime. "

Sir Paul Nurse, Cancer Research UK

Your research papers will be:

- available free of charge to the entire biomedical community

- peer reviewed and published immediately upon acceptance

- cited in PubMed and archived on PubMed Central

- yours - you keep the copyright

Submit your manuscript here:

http://www.biomedcentral.com/info/publishing_adv.asp
BiolMedcentral 